\title{
IRISH FILM AND TELEVISION - 2015
}

The Year in Review

\author{
Roddy Flynn, Tony Tracy (eds.)
}

Copyright (c) 2015 by the authors. This text may be archived and redistributed both in electronic form and in hard copy, provided that the authors and journal are properly cited and no fee is charged for access.

The Irish Are Coming: Irish Film and Television in $\mathbf{2 0 1 5}$

Roddy Flynn and Tony Tracy

The Canal (Ivan Kavanagh 2014)

Ciara Barrett

Brooklyn (John Crowley 2015)

Pat Brereton.

Swan Song: Lamenting Ireland's Traditional Past in

Song of the Sea (Tomm Moore 2014)

Liam Burke.

The Making of a Western in Conamara: An Klondike (Dathai Keane 2015)

Sean Crosson...

Sentimentality and "Difficult" Art in Room (Lenny Abrahamson 2015)

Eileen Culloty

Queen of Ireland (Conor Horgan 2015)

Debbie Ging

Performance of Myth: The Legend of Longwood (Lisa Mulcahy 2014)

Loretta Goff

My Bonnie (Hannah Quinn 2015)

Isabelle le Corff

A Revision of the Family in Irish Film: Glassland (Gerard Barrett 2015)

Deirdre Molumby

The Great Wall (Tadhg O'Sullivan 2015)

Michaela Marková

Rebellion (Colin Teevan / RTE 2016)

Sheamus Sweeney

I Used to Live Here (Frank Berry 2015)

Tony Tracy 


\title{
The Irish Are Coming: Irish Film and Television in 2015
}

\author{
Roddy Flynn and Tony Tracy
}

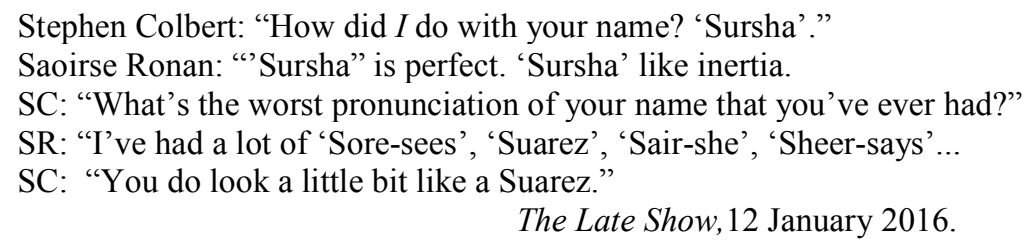

Recent months have seen the "absurd" discrepancy between the spelling and pronunciation of Saoirse Ronan's first name repeatedly exploited for comic effect on the American chat show circuit. Before Colbert, Ellen de Generes did it twice (producing cards with Irish names and challenging the audience to guess the correct pronunciation) while Jimmy Fallon couldn't avoid referring to the Ronan's brogue during a Tonight Show appearance in November 2015. Behind the cheap laughs, however, these exchange simply that US audiences need to get used to Irish accents and idioms (Interview magazine featured a similar encounter between Domhnall Gleeson and Angelina Jolie), pointing to a 'mainstreaming' of young Irish actors and - perhaps - Irish film within the US entertainment firmament. ${ }^{1}$

This 'greening' owes much to the critical success and extensive coverage afforded two recent Irish films - the screen adaptations of Brooklyn and, to a lesser extent, Room (reviewed in this year's edition by Pat Brereton and Eileen Culloty respectively) - although for a variety of reasons, Saoirse has proven the more marketable personality. In the case of Brooklyn, the remarkable success of Colm Tóibín's novel was replicated by John Crowley's screen version. After

1. "So, Brad had a question for you. What the hell is the $M$ doing in your name if you're not going to use it?"Angelina Jolie to Domhnall Gleeson, Interview Magazine, 6 April 2015. premiering at the Sundance Film Festival in January 2015 , a carefully planned festival release strategy built critical momentum over nine months, paying dividends on the US and UK awards circuits, most notably for Saoirse Ronan's central performance as Eilis.

The comparable success of Lenny Abrahamson's Room (the nomination of Abrahamson in Best Director category in some senses outshone Brooklyn's considerable achievements) came as a late bonus given that the film didn't receive a world premiere (notably at Telluride, not Dublin) until September 2015. Both films featured prominently among the nominees for the Screen Actors Guild, the Golden Globes, the New Film Critics Awards and, of course the Academy Awards. When Colin Welland, on receiving the Best Screenplay Oscar for Chariots of Fire in 1982, famously proclaimed that "the British are Coming", he could only point to that single film. In 2016, the Oscar nominations created a hitherto unimaginable scenario: two Irish films vying not only in the Best Actress Category but also for the high status and financially critical Best Picture Oscar. The Irish, it would seem, have arrived.

So overwhelming has the critical praise and coverage of these films been that they have all but eclipsed other films produced in Ireland over the past year and become, inevitably perhaps, the benchmarks by which such films are measured. Notwithstanding their extraordinary achievements, Brooklyn and Room nevertheless raise provocative 
issues around the definition and ambitions of Irish cinema in 2016. (Along with the not-yet unreleased Viva - a Cuba-set Spanish language film shortlisted as Ireland's entry in the Best Foreign Language category). While Room can unproblematically be identified as Irish at a production level, led by director Lenny Abrahamson and producer Ed Guiney (and substantial development and production funding from the Irish Film Board), the setting and characters are unequivocally North American. Outside Ireland, some media coverage has referred to the film as Canadian, reflecting Guiney's creative exploitation of screenwriter Emma Donoghue's dual Irish/Canadian citizenship to access Canadian funding. (The film is adapted from Donoghue's novel). In this regard it's worth recalling that the previous Abrahamson/Guiney collaboration, Frank (2014) had scarcely any textual relationship to Ireland at all (bar a brief stop-over for the band) and while two of its principle actors were Irish - Michael Fassbinder and Domhnall Gleeson - they were cast as American and British characters respectively.

Brooklyn, of course, is an overtly Irish text. Based on Irish writer Colm Tóibín's novel, it stars the most prominent Irish screen actress since Maureen O'Hara in a familiar story of Irish emigration to the United States. Director John Crowley was previously best known for Intermission (2003) and the Irish Film Board, the Broadcasting Authority of Ireland and - in a rare move - RTE contributed towards the production budget. But, as the producers acknowledged in an interview with Screen International, the rest of the budget was a patchwork of international finance: the UK (the BFI, the BBC, Lionsgate UK and the UK tax credit), Canada (Telefilm Canada and distributor Mongrel Media) and Australasia (Transmission Films), with some gap financing on top. Although Irish production company Parallel facilitated the Irish shoot and secured the Irish funding, they were clearly the junior partner in a production led by Londonbased Wildgaze Films. Tellingly - but somewhat awkwardly for any "Irish are coming" narrative the film qualified for the Best British Film category at the January 2016 BAFTAs, which it then won.

The point of all this is not to nitpick, or to undermine the efforts of the Irish Film Board, production companies and creative talent, which have unquestionably made decisive contributions to these productions. It is rather to raise the question of whether it even makes sense to think of Irish cinema in national terms anymore. And if not, then how might we conceptualise and relate the diversity of activities in Ireland's audio visual sector.

Admittedly this is scarcely an original observation, nor is it one that uniquely applies to Ireland: for at least two decades, the idea that national cinemas can be treated as discrete entities has been increasingly difficult for the film academics to sustain. From the early 1990s, when scholars like Stephen Crofts and Andrew Higson sought to delineate the range of approaches which might be included under the rubric of national cinema, they had to include some categories which, on the fact of it, seemed to have very little to do with the notion of the national. Croft's "Imitating Hollywood" category (into which he placed much Anglophone production from the UK, Australia and Canada) noted the extent to which such nations had become offshore production bases for Hollywood. While this has some bearing on Ireland - more in relation to high-end television than film these days, it does not quite capture the complexities of the situation.

For some years, this annual Review has traced an evolving trajectory whereby Irish screen policy has, in line with the wider industrial policies of Ireland's open economy, sought to 'balance' what might be described as cultural priorities with a desire to maximize the potential for foreign investment - through tax breaks, coproductions, location facilities or other means. Behind the celebration of 'Irish' film, such policies continued to be developed this year by Minister for Finance Michael Noonan's October 2015 decision to raise the cap on eligible expenditure using the Section 481 tax credit to $€ 70 \mathrm{~m}$, a figure simply not relevant to Irish indigenous production. Similarly, in November 2015 a subsidiary of Ardmore, Troy Studios signed long term deal with Limerick City and County Council to lease the former Dell Factory in Castletroy (a company once attracted to Ireland for tax purposes but who have since relocated to 
cheaper Poland), promising to add 70,000 square feet to the existing 110,000 sq. foot of studio space already in Ireland, clearly with a view to luring international film and TV productions.

Such policies have borne fruit for Ardmore who are clearly keen to extend their successful business model: in March 2015 the History Channel renewed Vikings for a fourth season whilst the third season of Showtime's Penny Dreadful began shooting at Ardmore in September. Having been revived by Amazon Prime for a third series, Ripper Street secured a further two season renewal from the online retailer (and a Royal Television Society award to postproduction house Screen scene for their work on the series). Additionally, of course, in September 2015, the Star Wars franchise returned to the Skelligs to begin principal photography on Episode VIII.

The scale of studio expansion suggests an expectation that Ireland will share in anticipated future global production growth. This is a highly contested market - even within the boundaries of this small island. Similar strategies north of the border are paying serious dividends, perhaps to the detriment of inward production levels in the Republic. The Northern Ireland Screen/Invest NI-backed Game of Thrones (now in it sixth season on HBO) continued to shoot at Titanic Studios and carry out some of it post-production activity in Belfast. Endemol's large budget series The Frankenstein Chronicles completed an NI shoot in 2015 and there were renewals for two major BBC police procedurals shot there, Line of Duty and The Fall. Even the Brad Pitt-produced Lost City of $Z$ feature spent five weeks in Belfast.

Regardless, the bifurcatory manner in which the Review has traditionally characterized the Irish screen industries - a financially dominant overseas production sector on the one hand and (much) smaller scale indigenous production on the other - no longer captures the complexities of the sector. It may now be worth considering a third, overlapping category that encompasses content, production and distribution contexts: a transnational Irish 'cinema'.

In her survey of how the concept of transnational cinema has been deconstructed and reconstructed Deborah Shaw, identifies fifteen possible modes. Key amongst these are transnational practices of production, distribution and exhibition, such as co-production funding and marketing films to global audiences. ${ }^{2}$ This is suggestive for Room, a transnational film at the level of funding but where the primary imagined audience is unlikely to ever have been only Irish. Since Room, Abrahamson has been linked with a plethora of subsequent projects which - like his past two projects - are textually unconnected to Ireland. These include the story of the gay New York boxer Emile Griffith, a possible adaptation of Laird Hunt's novel Neverhome (about a woman who disguises herself as a man to fight in the America Civil War) and an adaptation of Sarah Water's supernatural post-World War Two novel The Little Stranger. If, as Eileen Culotty suggests in her review of Room, the film is in part a "calling card" to Hollywood, then clearly it has been heard. Less interested in the socio-political complexities of the local than Abrahamson's first three films, and set in a non-specified, 'vanilla' North America, Room is a transnational art house film (or Hiberno-Anglo-American at any rate), that eschews the social for the personal, even as it makes strong use of Irish production talent and finance.

It is not unique. Paddy Breathnach's new film Viva, just missed out on making the shortlist for Best Foreign Language Film for the 2016 Oscars. However, the language in question was not Irish but rather Spanish, since the Mark O'Halloran-penned script was entirely filmed in Cuba and shot through Spanish. For his part, having made two examples of resolutely national films in Pilgrim Hill and Glassland, Gerard Barrett's next feature is Brain on Fire, a IrelandUS-Canada production filmed in Canada with Chloe Grace Moretz (Kickass) in the lead role. Finally Juanita Wilson (As if I was Not There) has just completed shooting Tomato Red, an Irish-Canadian co-production set in the Missouri Ozarks, starring a largely American cast but with key Irish talent in the roles of cinematographer Piers McGrail (Out of Here), and composer Stephen

2. Deborah Shaw, "Deconstructing and reconstructing 'transnational cinema",, in: Stephanie Dennison, ed. Contemporary Hispanic Cinema: Interrogating the Transnational in Spanish and Latin American Film (Woodbridge, Suffolk: Boydell \& Brewer, 2013). 
Rennick (What Richard Did, Frank, Room).

Stephen Crofts has also made reference to the risk that Anglophone cinemas may fall prey to Hollywood vampirism, i.e. talent poaching. In this regard the recent ascent of younger Irish actors in the Hollywood firmament has been remarkable - to the established names of Neeson, Brosnan, Byrne, Farrell and (Brendan) Gleeson, the last half decade has seen Saoirse Ronan, Fassbender (nominated this year for a Best Actor Oscar for his performance in Steve Jobs [2015]), Domhnall Gleeson (over Christmas 2015 - multiplexes were running a mini-season of his work in the shape of Brooklyn, The Revenant and Star Wars: The Force Awakens), Andrew Scott (Spectre), Aidan Gillen and Chris O'Dowd come to the fore. The argument might be made that establishing such star power overseas affords those actors the opportunity to lend their names to indigenous projects. The question is to what extent this actually happens. In some cases, the answer is clearly yes: Brendan Gleeson intersperses character roles in US productions with lead roles in Irish-originated films. Andrew Scott's turns in John Butler's The Stag and - this year - Handsome Devil were separated by appearances in Spectre and a reprise of his Moriarty in the BBC's Sherlock Holmes. In many cases, however, these younger actors are developing Anglo-American star personas whereby they move between a geographical range of projects and residences. Fassbender is perhaps the most striking example but Saoirse Ronan and Domhnall Gleeson are also examples of actors seen as both Irish and transnational.

As already indicated the transnational character of contemporary 'Irish' cinema is less value laden when discussing production talent, particularly in relation to TV drama which is seen as intrinsically transnational in the age of Netflix and Sky Atlantic. Director of Photography John Conroy moved from Penny Dreadful to key cinematography on Sky's Fortitude and the second series of ITV's Broadchurch. PJ Dillon who lensed the IFBsupported Australian drama Strangerland also saw his work on Penny Dreadful earn a British Society of Cinematographers award nomination. Director Ciaran Donnelly has forged a strong international reputation with big budget productions such as Vikings, A.D. The Bible Continues and Crossbones. Daniel O'Hara, director of one of the best Irish shorts of the $21^{\text {st }}$ century ( $Y u$ Ming is Ainm Dom) directed two episodes of Doctor Who.

This international focus is not limited to individuals. The perpetually ambitious Element Pictures will not only produce Lenny Abrahamson's next overseas picture (whatever it turns out to be) but will reprise their collaboration on The Lobster with Greek director Yorgos Lanthimo on The Favourite, a story set in the 17th century court of Queen Anne and possibly the director's mooted supernatural thriller The Killing of a Sacred Deer. They have also reprised their relationship with Polish director Jerzy Skolimowski's for 11 Minutes, his follow-up to Essential Killing (2010) which they also co-produced.

Amidst all this, the once core element of the Irish screen industry - indigenous production endures and in some cases thrive. In this issue we review I Used to Live Here, a micro-budget and socially committed exploration of teen mental health set in working class Dublin. Frank Berry's deeply responsible and patient effort deserves to be viewed and praised. Stephen Bradley's bio-pic Noble garnered much critical attention and was widely distributed internationally as was Mark Noonan's lowbudget debut You're Ugly Too which was not only released in South Korea, Israel, Turkey, Denmark, Romania and - on 50 screens - also in Germany and secured a showcase screening as the Directors Guild of America theatre in Los Angeles having won the Directors Finders series. There remains a discernible shift towards overtly generic work within indigenous features. To the horror genre discussed in these pages in previous years, we can now add Ivan Kavanagh's The Canal (also reviewed here), Corin Hardy's The Hallow, and Brian O'Malley's Let Us Prey. In the fantasy/sci-fi mode, there was the children's film The Legend of Longwood (included in this year's review) and Stephen Fingleton's The Survivalist. Cardboard Gangsters and Paul Mercier's Pursuit can be broadly described as thrillers whilst Darkness on the Edge of Town is 
a neo-western (appropriately shot on the west coast in Kerry) from newcomer Patrick Ryan. While there is some fine work on display in all these films (Pursuit features a stellar Irish cast include Liam Cunningham and Brendan Gleeson), none have made much impression with the wider public. The reasons for this deserve wider examination. One possible explanation is that average production and publicity budgets for such films remain generally low, increasing their appeal to newbie film makers but also reflecting the effective freeze in the Film Board's capital budget at $€ 11.2 \mathrm{~m}$ in 2015 - an almost comically small budget given the success and activity within the sector.

It is perhaps telling that unlike so many contemporary fiction films set in Ireland, the Feature Documentary format continues to enjoy relatively rude health; creatively, socially and, more pointedly, commercially. For a country that seems to have been constantly negotiating social change over the past two decades, documentary seems to reach the places of Irish experience that fiction cannot. Following on from the success of One Million Dubliners in 2014, several docs made an impact in 2015. Older than Ireland from Snackbox Films (who previously produced the well-received The Irish $P u b$ ) demonstrated the ongoing potential of the talking heads approach. Dignified and humorous this assemblage of the lives and experiences of Irish centenarians earned $€ 160,000$ (on an $€ 100 \mathrm{k}$ budget from the Irish Film Board) in Irish cinemas and enjoyed the best opening on DVD of any Irish film in 2015. Conor Horgan's biodoc on Panti/Rory O'Neill The Queen of Ireland (reviewed here by Debbie Ging) had the third best cinema opening of any documentary (after Fahrenheit $9 / 11$ and Amy) at Irish box office, taking $€ 110 \mathrm{k}$ by January 2016 . There were also significant contributions to the genre from Se Merry Doyle - (the Arts Council-funded Talking to My Father on influential Irish architect Robin Walker) and Pat Murphy's Tana Bana, a poetic exploration of the impact of globalization on the silk weavers of Varanasi on the Ganges River in India. In October, director Ciarín Scott won the George Morrison Award at the IFTA for an unflinching study of Christina Noble (the subject of the fiction film Noble mentioned above) and her harrowing Dublin upbringing. Two other docs - Fortune's Wheel (about a lion-tamer based in Dublin's Fairview in the 1950s) and $A$ Doctor's Sword (the remarkable narrative of a Cork-born doctor who as a WWII prisoner of war survived the atomic bombing of Nagasaki) enjoyed unexpectedly long runs in the localities connected to their respective narratives, clearly demonstrating the appeal of local stories to (intensely) local audiences. Finally, although it technically belongs to next year's review it is worth noting that the most powerful piece of audio-visual work commemorating the Easter Rising has been the sumptuous University of Notre Dame-funded documentary series 1916. Co-directed by Ruan Magan and Pat Collins with a Liam Neeson narration, 1916 succeeded not only in delineating the "long history" of the Rising in a clear and engaging manner, but also commercially, selling to an extraordinary 120 television stations across the US and UK.

Overall 2015 was a relatively quiet year for Irish television drama. In straight drama, although Telegael's production of three episodes of the Jack Taylor franchise (with Iain Glen) and RTE's Wexford-based Clean Break ensured some continuity of crime drama, Love/Hate was conspicuous by its absence, having dominated Irish ratings for its first five series. Its absence seems likely to be short-lived as a sixth series has reportedly been commissioned with previous series sold internationally to UK, US, Australia, New Zealand, Asia, the Middle East, Australia and South Korea. The hiatus is notionally to permit additional time to refocus a show that, of its nature, has seen most of its characters suffer violent expirations. However, given RTE's finances, it seems likely that it was impossible to contemplate funding both Love/Hate 6 and the 1916 centenary-themed series Rebellion. The $€ 6 \mathrm{~m}$-budget series (reviewed here by Seamus Sweeney) was not critically well-received although its heavy promotion saw it maintain respectable audiences (500,000 plus per episode) even after negative reviews. (These will be augmented by those US viewers who watch is via via the Sundance TV cable channel later in 2016). Elsewhere TG4's scheduling of the Abu 
Media-produced An Klondike (reviewed here by Sean Crosson) tapped into the Deadwood market, leading to a subsequent sale of the series to Netflix UK (where it screens as Dominion Creek). Taken together, along with the sale of TV 3 soap opera Red Rock to Amazon Prime, we see an increasingly transnational pattern emerging in small screen production and distribution.

If there is a field of screen production that has long been recognisably Irish, it has been the indigenous animation sector. Song of the Sea (reviewed by Liam Burke) ultimately lost out to Disney's Big Hero 6 at the 2015 Oscars, but Cartoon Saloon have enjoyed remarkable success by having both their last features nominated by the Academy. Saloon's success is not limited to the big screen - the Chris O'Dowd-voiced Puffin Rock was nominated at the 2015 Miami Kidscreen awards. For their part, Jam Media saw their long-running $\mathrm{BBC}$ series Roy spawn not one but two spinoffs for CBeebies and CBBC commissions, while relative newcomer Geronimo successfully sold their Nelly and Nora series to CBeebies. However, the main animation story of the year, saw a potentially significant dilution in Irish control of the indigenous animation sector in the sale of Brown Bag Films.

Brown Bag has long been the star performer of the indigenous sector, as they moved from commercials work to Oscar-nomination success of Give Up Yer Aul Sins in 2001 and ultimately into serial production for a range of international markets, working on both original content (Granny O'Grimm) and producing work based on children's books (Peter Rabbit, Olivia, Henry Hugglemonster etc.) 2015 saw two of their current show - Doc McStuffins and The Octonauts nominated for Producers Guild of America awards. In August 2015 Brown Bag was sold to 9 Story Media Group, a Toronto-based 2-D animation company. Though framed as a means of developing Brown Bag's distribution reach (whilst bringing the former's 3-D animation heft to 9 Story), the sale raises questions as to the extent to which the interests of Brown Bag (which employ over 200 in Dublin with an additional operation in the UK) interests will be subordinated to those of the new parent. If the corporate element of 9 Story's website is accurate, neither Cathal Gaffney and Daragh O'Connell, the founders of Brown Bag, have been offered senior positions within the higher echelons of 9 Story.

Overall then, 2015 saw a wide variety of developments that augur well for the continued stability and development of a diverse and thriving Irish audiovisual sector. Some of those achievements have been incredible by any standard and represent an ever-growing economy of experience and confidence that would have been unrecognizable twenty years ago. As we reflect on the success and diversity of the sector we recognize that the reality of Irish national cinema, while still the totemic and structuring principle of moving-image production (symbolically and financially), is quite different from what was once meant - and aspired to - by that term. Thus in framing this year's review we have begun to consider a conceptualization of transnational cinema as a means of recognizing both the national and international contributions to that broad effort multiple levels that include content, financing, production, stardom and distribution. As Irish film is increasingly understood and supported on the level of production (finance, personnel) rather than content, the era of the transnational brings with it evident rewards but also risks to the critical and aesthetic function of the local.

Roddy Flynn is a lecturer on film and television at the School of Communications, Dublin City University where he is current Chair of Film and Television Studies. He is co-author (with Pat Brereton and Tony Tracy of the forthcoming second edition of The Historical Dictionary of Irish Film (Scarecrow 2016) and (with John Horgan) of the forthcoming Irish Media: A Critical History (Four Courts 2017).

Dr. Tony Tracy lectures in film theory and history at Huston School of Film and Digital Media, NUI Galway where he directs the BA programme. His research specialisms are Irish Cinema and silent and classical era Hollywood. His most recent publication is "Outside the System: Gene Gauntier and the Consolidation of Early American Cinema", Film History: An International Journal 28.1, 2016. 


\title{
The Canal (Ivan Kavanagh 2014)
}

\author{
Ciara Barrett
}

Thanks to digital film and the possibilities it presents for rapid and cheap filmmaking with relatively sophisticated special effects offerings in post-production, the last ten years have seen a proliferation of horror films shot in Ireland by Irish directors. These films, which include Boy Eats Girl (Stephen Bradley 2005), Shrooms (Paddy Breathnach 2007), Stitches (Conor McMahon 2012), and Grabbers (Jon Wright 2012), have inclined towards a pulp-postmodern sensibility and aesthetic by generic convention. Arguably, this is all the more informed and complemented by their essential Irishness, being confirmedly small-time and gleefully camp. Ivan Kavanagh's The Canal, however, may be seen as marking a departure from this pulp-Irish cycle as a Serious Horror that conceals, rather than reveals, its Irish location (in both geographic and psychological-identificatory senses) towards an overall project of dislocation and disorientation.

Boasting relatively high production values for a low budget under $€ 1$ million, The Canal deploys minimalist yet effectively horrific visual effects (by Bowsie Workshop, the Irish company that also provided effects for Stitches) in an incredibly efficient manner, amplified by Ceiri Torjussen's musical score and a sophisticated sound design. The Canal exchanges gratuitousness of gore for layers of atmospheric dread and disorientation on behalf of both its protagonist David (Rupert Evans) and the audience, whose subjective perspective is purposely linked and confused with his mounting hysteria. Indeed, thematically and in the context of its generic and national filmic heritage, The Canal is concerned with slippage and the dissolution of borders.

Plot-wise, the film blends psychological thriller with a poltergeist-horror film premise: David, a film archivist, moves with his pregnant wife into an old house that abuts onto a grim-looking canal (the exact geographic location of which is, importantly, unspecified: the film was shot in Dublin, but in the absence of any identifiable landmarks, the setting could be anywhere). Five years on, at the same time he and his wife Alice (Hannah Hoekstra), now loving parents to their son Billy (Calum Heath), are having marital difficulties (they are seen having awkward and perfunctory sex at home, and Alice flirts with a coworker at a work function), David views old newsreel footage that would seem to reveal their house was the scene of a crime over a hundred years earlier. At this point, David suffers a psychic break, though whether this is as a result of his failing marriage or from a sort of spiritual possession is unclear: he experiences visions of graphic violence and becomes simultaneously obsessed with historical murdersand with his wife's fidelity. Tracking his wife to an assignation, David dreams/witnesses her assault by aphantom killer. When Alice's body is found in the canal, and evidence of her adultery comes to light, David seeks to prove the influence of sinister forces and clear his name by capturing the ghosts he sees on film. Along the way, he tries unsuccessfully to persuade his son's nanny (Kelly Byrne) and his coworker Claire (Antonia Campbell-Hughes) towards his thinking. Following Claire's demise, which is visualised first subjectively/according to David as an attack by a ghost he filmed at the canal, and re-viewed later, from an alternate/objective perspective, as an assault by David, he acknowledges his own culpability in the death of his wife. This alternate reality is shown through a series of point-of-view flashbacks, which are presumed to be David's recalled memories. David himself then drowns after being chased through a tunnel that connects his house to the canal, as he is pursued by the police and by a ghost-vision of Alice. In the end, 
Billy, their surviving son, is about to be led away from the home, but he hears his father speaking to him from a crack in the wall: seeming final proof that David's visions were, on a level, real, for he has now become the ghost who haunts the house.

Taken altogether, the film juxtaposes two different versions or levels of reality in conflict with each other: David's experience of reality, which is dreamlike and non-linear, alternating always between past, present, and the inbetween, and the objective story world's, which operates according to rational and linear principles of causation (David is a jealous husband, ergo he kills his wife; David feels guilt, ergo he constructs an alternate reality that shifts the blame away from him: ghosts killed his wife). What is ultimately so unsettling and clever about The Canal is that the film refuses, in the end, to privilege one version of reality over the other. David's poltergeist narrative and the 'real world' jealous husband narrative co-exist without, ultimately, satisfying a narrative drive towards the revelation of which version of events really took place, and why. In other words, the audience is never quite certain whether they are experiencing/witnessing events from David's subjective viewpoint or from an objective perspective outside his psychological space.

This follows from the film's being shot and edited according a dreamlike aesthetic: jump cuts destabilise the spatio-temporal integrity of seemingly mundane narrative moments like David and Alice walking through their new house in the opening sequence, while the layering of various diegetic and acousmatic sounds expand the perceptible, physical limits of the screen space. The film thus builds an otherworld of narrative, tensions from which the audience is never fully released, as The Canal provides a purposely unconvincing retreat from David's dream/ghost-world: After Billy listens to his father through the wall, he gets into a car that will take him away from the house forever. Seconds later, however, he jumps from the moving vehicle, and the film's last shot is of Billy, back in the house - either having survived the jump, or having now become a ghost - closing the door on the audience and engulfing them in literal and metaphorical darkness.

It is, of course, a trope of classic horror films, from The Blob (Irvin Yeaworth 1958) to Paranormal Activity (Oran Peli 2009), that they pose a literal or figurative question mark over their ending. In this case, The Canal departs neither from broad generic convention nor from Irish-horror narrative tradition. What distinguishes The Canal, however, is its essential credulousness in horror as a 'serious' genre. It is postmodern, for sure, as borne out in its selfreflexive references to filmmaking, viewership, and the (re)construction of narrative, but it is never pulpy: the murder scenes, for instance, are not played outwardly for spectacle in and of themselves but rather to punctuate narrative: they are glimpsed fleetingly, thus illustratively, rather than tortuously in their duration. Similarly, the special effects by Bowsie Workshop are restrained and, for that, effective, maintaining a less-is-more approach to visualisation. Thus, when the script calls for horrific images - such as when David encounters the ghost-corpse of Alice in the bowels of the canal tunnel giving birth to a putrid foetus - the audience has not yet become inured to them. In such a way, The Canal maintains an effect of disorientation and destabilisation to the last, without resorting to camp performance and over-the-top visualisations, such as those purposely employed in Irish comedy-horrors like Boy Eats Girl or Stitches.

Further distinguishing The Canal from its Irish horror film predecessors - and compounding its overall disorienting effect - the film (purposely or not) appears curiously self-effacing of its root Irishness. As an Irish Film Board production, financed under Section 481 as an incentive to film in Ireland, The Canal is rather incidentally Irish, and its avoidance towards geographic contextualisation would appear to show Kavanagh's willful aversion here to invoking the spectre of Irish National Cinema (there are ghosts enough in the film, after all). Therefore there are no farms, no pubs, no nods to irreverent humour - tropes of the pulp Irish horror - to provide a cultural context and genealogy to the 
film. In such a way, The Canal seems as displaced as its mentally unstable protagonist.

Recalling the disorientating effects and affects of its narrative, the characters/actors of The Canal literally speak to the film's cultural dislocation and de-centredness. Out of the six main characters - David, Alice, Claire, nanny Sophie, Billy and the detective MacNamara (Steve Oram) - two (Claire and Sophie) speak with Irish accents, while the rest speak primarily with British accents or, in the case of Alice/Hannah Hoekstra and the woman who plays her mother, with Dutch accents. While on the one hand it could be argued this reflects the increasingly multi-cultural demographic of modern Ireland, mirrored by the film's self-consciously transnational circumstances of production, the fact that The Canal avoids explicit location within Dublin, and indeed erases any implicit references to such - the cops wear 'police' as opposed to 'garda' badges, as an example would seem to suggest that Kavanagh is putting national cinema discourses aside in search of the broader, global reach of postmodern genre filmmaking production (such as Korean horror cinema, for instance, has achieved).

Of course, just because a film or its director rejects the 'national' and/or the culturally specific within its text does not mean it cannot be reclaimed, (re)appropriated and/or analysed by cultural theorists as retaining implicit national/ cultural signification and import. This is, after all, what historians of Irish Cinema have had to do, to flesh out the body of Irish National Cinema by reading Irishness back into, or against the grain of, film texts. One of the things that is so interesting about The Canal, however, is that it has been so self-consciously bled of any residual, textural Irishness (if it has not been bled of the Irish money that funded it), towards the intentional (or, again, not) effect of the unheimlichkeit, the sense of being in a home that is not home, haunted by the ghosts of Irish Cinema past.

Ciara Barrett is Film Studies Fellow at the Huston School of Film and Digital Media, NUI Galway. 


\section{Brooklyn (John Crowley 2015)}

\section{Pat Brereton}

In her 2004 Irish National Cinema Ruth Barton codified the notion of the Irish Heritage film, referring to a cycle of 1990s Irish productions which she described as characterised by "a nostalgic, Edenic view of Ireland". Though these films were primarily set in the 1950s, Barton argued that they describe an Ireland of the present, distinguished by its 'pastness'. Barton describes this as a feature of rural Irish films drawing on a British tradition of the heritage film, emphasising a fantasy of innocence and whimsy, the appeal to a rural past and a touristic future now the most recognised manifestation of the genre in an Irish context. She concludes her thesis by arguing that 'Ireland's recovered history is metonymic for a universal loss of innocence, displacing its function as locus of heritage nostalgia' (Barton, 149-56). In that respect is it striking that one reviewer - Mark Kermode in the Observer (Sunday $8^{\text {th }}$ Nov. 2015) - wrote of Brooklyn that it "beautifully evokes the sense of being torn between time, place and identity. In Ireland, Eilis is a daughter with a history; in America she is a woman with a future; in both she is filled with displaced longing'.

Brooklyn is arguably the most internationally successful - both critically and financially indigenous Irish film since John Carney's Once. Empathetically adapted by Nick Hornby from Colm Toibín's novel, it tells the story of Eilis (Saoirse Ronan - the 'Maureen O'Hara for a new generation'), a young woman from Enniscorthy, County Wexford who emigrates to America where she hooks up with Tony (Emory Cohen), a Brooklyn plumber, neatly fulfilling the romantic drive of such a melodramatic narrative.

Reviews of Brooklyn, have invoked its particular nostalgic appeal, while occluding its somewhat conventional generic features. Kermode eulogised:

What a moving, emotionally intelligent and refreshingly old-fashioned movie this is. The narrative may be perfectly situated in the early ' $50 \mathrm{~s}$, but the style of filmmaking harks back further still, to a time when "women's pictures" were the backbone of popular cinema.

Other reviewers have emphasised its appeal in promoting a surfeit of 'feel good' nostalgia and a solid sense of place and time while tapping into the perennial emigrant condition - initial feelings of loneliness and isolation, followed by adaptation and the assimilation of the emigrant. As Glenn Kenny's review for rogererbert.com (Nov. $\left.4^{\text {th }} 2015\right)$ explains that Eilis is "terribly vulnerable":

In the film she has a beloved mam and older sister (the adaptation excises the older brothers in the novel) and once ensconced in a quasi-boarding house in a nicely brownstone-and-tree-rich neighbourhood of the New York borough to which she's sailed, she misses them terribly.

The filmic result is clearly director John Crowley's most successful picture since 2003's unexpected punchy Intermission. Elsewhere, I have suggested that Intermission can be considered as Ireland's first "smart movie" (Brereton 2012: 104) and as such represented a significant development in terms of how Irish filmmakers sought to appeal to contemporary audiences. By contrast, Brooklyn is formally safer, suggesting a reversion to more established generic and commercially fine tuned material.

In this regard it is worth recalling that while Intermission was one the most commercially successful films Irish Film Board funded films, taking over $€ 2.3 \mathrm{~m}$ at the Irish box office, it did 
not repeat this feature on the other side of the Atlantic. When finally released in March 2004 by the Independent Film Company, it opened in only 10 theatres in America, taking a paltry $\$ 39,540$ in its opening weekend.

Brooklyn in contrast has become a major commercial success earning over $€ 32 \mathrm{~m}$ in the US by February 2016 (and a further $€ 8 \mathrm{~m}$ in the UK and Ireland).

Irish film scholars have drawn attention to prior over-use of mythic excess in similar Irish films seeking to appeal to an American/diasporic audience, suggesting that they often collapse "into a kind of historicist nostalgia" through their "essentially regressive ideologies" (McLoone, 2000: 120). Such criticism might more accurately speak to an earlier foray into Irish émigré territory, Jim Sheridan's In America. That film received mixed reactions in this vein, criticised as over-sentimental with a sometimes confusing narrative logic. Brooklyn has learned from such dangers, and the resultant film is much more cohesive and engaging for mass audiences, adapting a coherent narrative and structure (drawn from original, successful novel).

Nonetheless, while relatively faithful, the adaptation adds a sequence of Eilis returning to America and re-igniting her marriage, perhaps reflecting the screen medium's demand for narrative closure. Similarly the sequence illustrating her first entry into America, magically appearing on the other side of Ellis island, is not included in the novel, but echoes Sheridan's penchant for mythical and magical excess. Having endured a difficult boat passage, Eilis is witnessed almost literally 'going into the light', emerging through a portal into the utopian space of America.

All emigrants must confront the tension between maintaining one's indigenous cultural identity, and the pressure to integrate/assimilate into the host society. This transition is managed by memorable yet archetypical support roles, most notably Mrs Kehoe (Julie Walters), Eilis's protective land-lady who maintains a hilarious distain for 'giddiness'. She is augmented by Jim Broadbent's Father Flood, an utterly benign priestly presence who assists Eilis to integrate. (There is no hint here of the trauma of child abuse or other forms of religious discontent commonplace in recent Irish filmic portrayals of the religious, such as Calvary).

Like In America or The Quiet Man, Brooklyn represents a celebration of an Irish-American encounter, the struggle to find acceptance, and secure a new and alternative family. Such a trajectory is frequently coded as conservative, in the ideological and sentimental readings of a Fordian or a Spielbergian aesthetic for example. For instance In America serves as an artefact of Irish-American expressions of identification and constructing a dialogical chain of equivalence, where America is in some ways the 'empty signifier', linking optimism, emancipation, opportunity, redemption, universalism, multiculturalism, magic and progress, while 'Ireland', is metaphorically chained to signifiers of loss, death and 'the emotional wounds of a past sorrow' (In America, DVD 2004). ${ }^{1}$ Meanwhile, one could argue that Brooklyn is more progressive, or at least more optimistic, in permitting the migrant to contemplate a return to Ireland - a possibility that is seldom if ever afforded in earlier Irish émigré tales. The novel usefully addresses this issue by suggesting that the experience radically changes the migrant, rendering them less timid or insular and more confident and appealing - even employable - as a consequence.

By contrast with the sepia-tinted visual palette, the use of indigenous sean nós music emerges as the film's most authentic feature. Diegetic music plays a storytelling role throughout the film, with the new verses and old choruses of Eilis's life rehearsed amid contrasting dancehall scenes. In a

\footnotetext{
1. At the outset this seems to reverse the 'touristic' Irish fixation of many Irish-Americans who make the reverse journey to Ireland. Stephanie Rains' evaluation of Irish-American identity and their "engagement with Ireland is not indicative of an antimodern romanticism that is to be compared with a realistic and modern Irishness. Rather, in this context, the nostalgia evident within the diasporic gaze should be seen as the self-interrogating framework through which the diaspora negotiates reconciliation between its narrativised collective history and its engagement with contemporary Ireland" (2007: 138).
} 
truly sublime sequence that echoes the raw poetry of The Pogues' Christmas classic, "Fairytale of New York", Eilis is seen serving a communal Christmas dinner to the downtrodden men who "built the tunnels and bridges" of New York. Similar stories of manual labour are evident in Irish communities in London and elsewhere. One of the unsung migrants (played by angel-voiced Iarla O'Lionaird) stands up at the party to sing the traditional Irish love song 'Casadh an tSugain'. The scene evades cheap sentimentality by dint of the sheer emotional purity and lyrical engagement of the music.

In the original novel, Toibin paints a rich picture of the scene: "His voice was loud and strong and nasal; the Irish he sang in, she thought, must be Connemara Irish because she remembered one teacher from Galway in the Mercy Convent who had that accent. He pronounced each word carefully and slowly, building up a wildness, a ferocity, in the way he treated the melody. It was only when he came to the chorus, however, that she understood the words - 'Ma bhionn tu liom, a stoirin mo chroi'
- and he glanced at her proudly, almost possessively, as he sang these lines. All the people in the hall watched him silently" (2009: 90).

Wisely, Crowley allows O'Lionaird's voice to ring unaccompanied before Michael Brook's orchestration takes over, while focusing on a montage of silent faces offering fleeting portrait of homes left and loves lost. As a seminal and iconic Irish audio-visual image of exile, this is amongst the most memorable across the whole history of Irish cinema.

In a materialist and broadly secular Western culture, the need for some form of identification and belief in the benevolence of human nature, alongside creating strategies to cope with emigration, loss and even bereavement remain paramount. Given this it is perhaps unsurprising that a text which at one level is a generic émigré/heritage film has nonetheless succeeded in winning audiences in the US, speaking to and for the deeply held emotions of a diasporic Irish population who have made America their home.

\section{Works Cited}

Barton, Ruth. 2004. Irish National Cinema. London: Routledge

Brereton, Pat. 2012. Smart Cinema: DVD Add-ons and New Audience Pleasures. Basingstoke: Palgrave

Flynn, Roddy and Brereton, Pat. 2007. Historical Dictionary of Irish Cinema. Lanham, Toronto, Plymouth: Scarecrow Press

Kenny, Glenn. 2015. "Brooklyn”, http://www.rogerebert.com/reviews/brooklyn-2015, 4 November.

McLoone, Martin. 2000. Irish Film: The Emergence of a Contemporary Cinema. London: British Film Institute.

Rains, Stephanie. 2007. The Irish-American in Popular Culture 1945-2000. Dublin: Irish Academic Press.

Toibin, Colm. 2009. Brooklyn. Viking/Penguin

Professor Pat Brereton is the Head of the School of Communications at Dublin City University. Recent publications include Environmental Ethics and Film (Routledge 2015) and Smart Cinema (Palgrave 2012). 


\section{Swan Song: Lamenting Ireland's Traditional Past in Song of the Sea (Tomm Moore 2014)}

Liam Burke

In the 2008 Irish Film and Television Review for this journal I used the release of Tomm Moore's The Secret of Kells to chart animation's position within Irish national cinema. In concluding the review I suggested that, "Perhaps sometime in the near-future, the film representing Ireland at the Academy Awards will come from drawing on a national identity" (Burke 2009: 191). These comments seemed prescient just a year later when The Secret of Kells received an Academy Award nomination for Best Animated Feature. However further predictions proved less accurate with the review proposing that Tomm Moore's film, alongside the release of Magma Films' Niko \& the Way to the Stars (Hegner and Juusonen 2008), "found the Irish film industry on the cusp of achieving a consistent level of Irish animated feature production" (Burke 2009: 187). Sustained production of Irish animated features has not been realised in the intervening years, although a number of animation companies have become market leaders in television.

JAM Media, which has offices in Ireland and the UK, expanded its short film Badly Drawn Roy (Shannon 2006) about Ireland's only "living" animated character into the BAFTA Award-winning series Roy (2009-2015). Brown Bag Films achieved international hits in the preteen market producing animated shows like Doc McStuffins (2012- ) and Henry Hugglemonster (2013- ) for Disney Junior. Such was the success of the Dublin-based company, that Brown Bag Films was acquired by Canadian studio 9 Story Media Group in 2015 (discussed in the intro to this year's Review). Cartoon Saloon, which had already produced the animated series Skunk FU! (2007) prior to the release of The Secret of Kells, returned to television in 2015 with Puffin Rock about a pair of young puffins on the eponymous Island. Playfully narrated by Irish actor Chris O'Dowd the series is aimed at three to five year olds yet is realised in the same traditional animation that made The Secret of Kells a critical favourite. ${ }^{1}$

To hedge my bets on the success of Irish animated features I offered the caveat in The Secret of Kells review that, "It will be up to the box office to see whether this film becomes a standalone achievement, or the future tactic of Irish animated feature production" (190). Although The Secret of Kells did not find a wider audience, its critical, if not commercial, triumph has ensured that The Secret of Kells is not a singular success, with the 2015 release of Cartoon Saloon's latest feature Song of the Sea. ${ }^{2}$ Moore describes Song of the Sea as a "spiritual follow up" (Powell and Brown n.d.: 4) to The Secret of Kells in that it embraces a hand-drawn aesthetic to tell a story based on Irish folklore, in particular selkies - mythological creatures who

1. Prior to Puffin Rock Cartoon Saloon had collaborated with Chris O'Dowd on Moone Boy, with the company providing the title sequence and animated interludes for O'Dowd's coming-of-age sitcom.

2. According to box office analysis website The Numbers, The Secret of Kells grossed US\$3,582,797 internationally ahead of a US $\$ 8,000,000$ budget. While the film would have grossed significantly more through home video and streaming services it also only grossed $€ 72,700$ at the Irish box office (Hogan) with Moore reflecting ahead of the release of Song of the Sea that Irish people seemed sceptical about local releases, "There's something at play where Irish people are doubtful if it is not from a big studio. There's an embarrassment factor (over Irish films). If a Hollywood film is crap, you'll just laugh it off" (McGreevy). In contrast to its modest box office, The Secret of Kells was a critical success holding a $91 \%$ approval rating on the review aggregator site Rotten Tomatoes. 
live as humans on land but on entering the sea they shed their human form and become seals.

The film opens on a storybook-like scene replete with a watercolour aesthetic. A heavily pregnant mother Bronach (Lisa Hannigan) is painting a selkie-themed mural on a nursery wall with her young son Ben (David Rawle). Ben's father Conor (Brendan Gleeson), the local lighthouse keeper, checks on their progress just in time for Ben to explain to him (and the audience) the legend of the selkies. The fairytale opening is shattered by the apparent death of Bronach following the birth of Ben's sister Saoirse. Cutting to six years later the film picks up on the family at their lighthouse home where the impact of Bronach's death is still strongly felt. Conor has retreated behind his pain barely able to engage with his children, Ben openly torments his younger sister, while the imp-like Saoirse has yet to learn to speak. Yet, unbeknownst to Ben, Saoirse is the last of the selkies whose song is destined to return the fairies (or "Sidhe") to their spiritual home. This destiny is scuppered when Ben's city-dwelling Granny (Fionnula Flanagan) forces the children to move to Dublin. What follows is a road trip through an Irish countryside populated by fairy folk as Ben and Saoirse escape their Granny's clutches in order to return home where the last of the selkies might fulfil her fate.

After the Medieval setting of The Secret of Kells, Moore, hoping to appeal to a wider audience, chose a more contemporary backdrop for Song of the Sea with the film inhabiting a pre-Celtic Tiger Ireland. The director also enlisted screenwriter Will Collins, whose underseen first feature My Brothers (Fraser 2010), like Song of the Sea, was a 1980s-set road movie. While still primarily aimed at a younger audience, Moore and Collins have managed to avoid the exposition-laden sequences that stalled The Secret of Kells, and crafted a narrative that builds pleasingly to a tense climax on the open sea. While parents may not find the same narrative meat of a Pixar film, the film's stunning watercolour tableaux, which capture the changing light and subtle shades of the Irish countryside, are a joy for all. Borrowing a fantasy film trope familiar to anyone who has seen
The Wizard Of $O z$ (Fleming 1939), Ben and Saoirse encounter mythological analogues of their friends and family on their journey voiced by reliable character actors. Jon Kenny infuses both Ferry Dan and the Great Seanchaí with befuddled charm; Gleeson breathes life into the remote Conor and the giant Mac Lir whose heartbreak turned him into a stone island; while Fionnula Flanagan transforms her crotchety Granny into the villainous Macha, an owl-like menace who stalks the sibling's every move. Appropriately for a film titled Song of the Sea, the score, composed by Bruno Coulais in collaboration with Irish folk group Kíla, rounds out the film's traditional tone and atmosphere.

In his oft-cited article "The Concept of National Cinema" Andrew Higson notes "the politics of national cinema can be reduced to a marketing strategy", (1989: 37). Indeed there was some scepticism when The Secret of Kells was released that its explicit "Irishness" was an attempt to gain the support of government bodies, with Maria O'Brien suggesting that the film's focus on folklore rather than organised religion might be seen as, "exploitation of Irish myths to obtain funding within Ireland" (2011: 34). However, Moore responded to the dominance of national themes in his work by explaining, "This is the unique viewpoint I feel I can bring to the animation medium. I don't rule out eventually making a comedy set in outer space or something like that, but for now I am exploring the culture I grew up in" (Powell and Brown 5). Indeed, since his early Irish language comics An Sclábhai ("The Slave" 2001) and $A n$ Teachtaire ("The Messenger" 2003), which told the story of St. Patrick, Moore has maintained an interest in depicting Irish subjects. Song of the Sea continues that trend from the film's use of Celtic mythology to its eagerness to flit between Irish and English without explanation. This cultural specificity has enabled the film to stand out in a form of filmmaking crowded by ambiguously set capers.

Similarly Moore rejects the realism that dominates most animated features, a practice Paul Wells traces back to Walt Disney, "Even though Disney dealt with what was a predominantly abstract form, he insisted on verisimilitude 
in his characters, contexts and narratives" (1998: 23). As in The Secret of Kells, Moore embraces the expressivity of the animated form realising the world of Song of the Sea in an intricate patchwork of icons with disarming graphic simplicity - this is a film in which emotions are unapologetically represented by rainbows and thunderclouds. These countervailing tendencies national specificity and expressionistic animation - contributed to the film's rave reviews and another Best Animated Feature Academy Award nomination, even while it struggled to find a cinema audience. ${ }^{3}$

In Understanding Animation Wells suggests that "it may be claimed that animation is one of the most auteurist mediums available to the filmmaker" (1998: 245) in that the handcrafted nature of the form allows the filmmaker to more deeply penetrate a topic without the limitations imposed by live action. Yet, despite the rich potential of the form, the themes Moore tackles are very familiar. Martin McLoone noted that at the height of the Celtic Tiger Ireland found "itself in the position of selling itself abroad as both a dynamic and modern economy with a young, highly skilled and energetic population and as a thinly populated rural country with beautiful unspoilt scenery steeped in tradition and removed from the bustle of a busy world" (2000: 92). Moore engages with this tension between progress and the past explaining that Song of the Sea stemmed from a "trip to the West coast and my nostalgia for the pre-'Celtic Tiger' Ireland" (Powell and Brown n.d.: 5). Using the structure of the road movie, Moore illustrates this theme through an urban/rural divide with Dublin depicted as a Dickensian slum

3. Song of the Sea was nominated for Best Animated Feature at the $87^{\text {th }}$ Academy Awards alongside The Boxtrolls (Stacchi and Annable 2014), How to Train Your Dragon 2 (DeBlois 2014), The Tale of the Princess Kaguya (Takahata 2014) and eventual winner Big Hero 6 (Hall and Williams 2014). Song of the Sea holds a $99 \%$ approval on the review aggregator site Rotten Tomatoes, but, according to box office analysis website The Numbers, the film only grossed US $\$ 1,579,826$ in cinemas internationally. replete with impenetrable fog and burnt out cars while the closer the protagonists get to their coastal destination the more lush and magical their adventures become. Identifying this convention in Irish cinema McLoone summarises, "We have seen how Irish cultural nationalism was constructed, among other things, on an opposition between the country and the city. In its clearest form this opposition posited the traditional Gaelic purity of Ireland's western seaboard and islands against the corruption of Irish identity epitomised by the city of Dublin, the 'strumpet city' that had prostituted itself to foreign cultural influence" (2000: 201). ${ }^{4}$ Unsurprisingly, as a traditional animator in a digital world, Moore gravitates towards stories of artists trying to keep ritual alive: illuminated manuscripts in The Secret of Kells and the stories and songs of his most recent work. In doing so his films maintain a cultural nationalist dichotomy of the "further away from Dublin, the closer one got to the real Ireland" (McLoone 2000: 201).

Song of the Sea finds many thematic and narrative parallels with earlier mythologicallyinflected Irish family films such as Into the West (Newell 1992) and The Secret of Roan Inish (Sayles 1994). Into the West follows a pair of young sibling's efforts to escape Dublin on a (possibly magic) white horse and reach Ireland's west coast. Like Song of the Sea, the film concludes on the coast where the siblings reconcile with their widowed father and are briefly reunited with their deceased mother who has taken the form of a mythological animal. The Secret of Roan Inish focuses on a young girl, Jeni, from the city who is sent to live with her grandparents on the Irish west coast by her recently widowed father who is unable to care for her. Upon arriving at her grandparent's home Jeni learns the family secret that her younger brother was swept away and raised by a selkie. Ruth Barton argues that the focus on children in magic realist films Into the West and The Secret

4. Appropriately the statue of Molly Malone, the street hawker often depicted as a prostitute (Dolby), is one of the few landmarks visible in Moore's Dublin. 
of Roan Inish further reinforces cultural nationalist sentiment as it "indicates these films' failure to break with the paradigms of colonial representation with its infantilising tendencies" (2004: 150), a view that might also be applied to the fairy-like children and pastoral nostalgia of Song of the Sea. Yet, Moore goes some way towards reconciling this tension between progress and the past in the film's climax in which Saoirse sings her song "to send the fairies home across the sea", prompting Bronach to reappear to her family as a white selkie. Saoirse is given the option to continue onto the fairy world with her mother or stay and give up her selkie coat; she decides to stay. As the fairies begin to leave, taking with them the magic of Ireland's folkloric tradition, Bronach advises Ben to "remember me in your stories and in your songs". In the film's coda the reconciled family (Ben, Saoirse, Conor, and Granny) is shown to be much more content without the ever-present reminders of their personal and cultural past. These traditions, while no longer tenable, are not forgotten, but are maintained through story, song, and, as Moore demonstrates, cinema.

\section{Works Cited}

Barton, Ruth. 2004. Irish National Cinema. London: Routledge.

Burke, Liam. 2009. "Drawing Conclusions: Irish Animation and National Cinema”. Estudios Irlandeses 4. $187-91$.

"Companies". n.d. Animation Ireland. [Web accessed 25 February 2016].

Dolby, Karen. 2015. Auld Lang Syne: Words to Songs You Used to Know. London: Michael O’Mara.

Higson, Andrew. 1989. "The Concept of National Cinema”. Screen 30.4. 36-47.

Hogan, Louise. 2010. "Blockbuster Year for Cinemas as Box-office Takings Soar 11pc". Independent.ie. 18 January [Web accessed 26 February 2016].

McGreevy, Ronan. 2015. “Oscar-nominated Director: Irish People's Attitude to Film 'post-colonial”" The Irish Times 20 February [Web accessed 26 February 2016].

McLoone, Martin. 2000. Irish Film: The Emergence of a Contemporary Cinema. London: British Film Institute.

"The Numbers - Where Data and the Movie Business Meet". n.d. The Numbers. Nash Information Services, LLC [Web accessed 28 February 2016].

O’Brien, Maria. 2011. “The Secret of Kells (2009), a Film for a Post Celtic Tiger Ireland?”. Animation Studies 6. 349.

Powell, Lucy, and Jessica Brown. n.d. "Song Of The Sea - Production Notes". Studio Canal. Http://press.optimumreleasing.net/ [accessed 28 Feb. 2016].

Roxborough, Scott. 2015. "Irish Producer Brown Bag Acquired". The Hollywood Reporter, 18 August. Hollywoodreporter.com, [accessed 24 February 2016].

Wells, Paul. 1998. Understanding Animation. London: Routledge.

Liam Burke is the Course Director of Media and a Senior Lecturer at Swinburne University of Technology in Melbourne, Australia. His monograph, The Comic Book Film Adaptation: Exploring Modern Hollywood's Leading Genre, was published by the University Press of Mississippi in 2015. Past publications include the Pocket Essential Superhero Movies and the edited collection Fan Phenomena Batman (Intellect 2013). 


\section{The Making of a Western in Conamara: An Klondike (Dathai Keane 2015)}

\section{Seán Crosson}

The Western has been one of cinema's most enduring and versatile genres. Despite the various remarks on the "death of the Western" (Buscombe 1988: 268), the genre has reappeared in new forms, spaces and time periods. No longer is it confined between the $1860 \mathrm{~s}$ and 1890s on the Western frontier of North America; the Afghanistan set The Kite Runner (Mark Forster 2007) has been examined in terms of the Western genre (Kollin 2007: ix-xix) while a similar productive analysis could be undertaken of the Turkish film Once Upon a Time in Anatolia (Nuri Bilge Ceylan 2011), a work reminiscent (and not just in its title) of Sergio Leone's Once Upon a Time in the West (1968). It would seem therefore overdue for an Irish Western production, though some have suggested that John Ford's (the seminal Western director) Irish-set film The Quiet Man (1952) might be regarded as such (Byrne 2009: 30-41; Faraci 2016). Abu Media's An Klondike (Dathaí Keane 2015) certainly fits the bill and was welcomed in the considerable (and largely positive) Irish press coverage it received as "the first Irish Western" (e.g. Stacey 2015). In both the four-part series broadcast on TG4 and the edited, feature-length cut screened at the Galway Film Fleadh, the production is replete with many of the tropes of the Western genre; a setting in the $1890 \mathrm{~s}$ in Western North America (the Klondike region of the Yukon in north-western Canada); conflict between civilized order (represented by the local Mountie Sam Steele played by former Stunning member Steve Wall) and an apparently lawless frontier town, Dominion Creek; and an array of familiar iconography including recognisable Western attire, a local saloon -The Golden Nugget - , a confidence trickster, prostitutes, the local bigwig saloon owner and his gunslinging enforcers.
However what sets An Klondike apart from any previous Western is that most of the dialogue is conducted through the Irish language.

Almost ten years ago in issue 3 of Estudios Irlandeses, I published a piece on Irish language film and television. In part, 'From Kings to Cáca Mílis: Recent Trends in Irish Film and Television as Gaeilge', was responding to hopeful signs within film and television production in Irish (including the release of two feature films in Irish in 2007) in a context where the language continues to be under considerable pressure and some decline in the Gaeltacht - or Irish-speaking - parts of the country. One of the consequences of this decline has been the challenge it has presented to filmmakers wishing to produce convincing contemporary drama as Gaeilge. For Paul Mercier (director of acclaimed and award-winning Irish-Language film and television including the short Lipservice (1998) and the TG4 series Aifric (2006-2008)) there are primarily three areas in which filmmaking in the Irish language can be made with integrity: films set in the past, films set in the future or films that engage with the challenges of the Irish speaker in Ireland today. The producers of An Klondike have adopted one of the most innovative and productive approaches in this respect by setting their series among Irish emigrants in $19^{\text {th }}$ century Canada.

One of the strengths of this approach is that it is based on the actual historical experience of hundreds of thousands of Irish emigrants in the late $19^{\text {th }}$ century, allowing the producers to build on existing historical records and strong narrative accounts of the period. Among the most acclaimed modern Irish language texts is Micí MacGabhann's Rotha Mór an tSaoil (1959) - republished in English as The Hard Road to the Klondike (1962) -, which describes MacGabhann's

ISSN 1699-311X 
experiences during the Klondike gold rush, when an estimated 100,000 prospectors (many of whom were Irish) migrated to the Klondike region of the Yukon in north-western Canada following the discovery of gold there in August 1896. An Klondike draws much inspiration from MacGabhann's vivid descriptions of events and characters while other characters in the series are based on actual historical figures, including confidence trickster Soapy Smith (Michael Glenn Murphy), local officer Sam Steele (after whom Canada's fifth tallest mountain, Mount Steele, is named), Native American Skookum Jim (Julian Black Antelope), and Father Judge (Clive Geraghty), who became known as "The Saint of Dawson" for his work providing shelter, food and medicine to poorer and ill miners caught up in Klondike's gold rush.

A further more contemporary inspiration for the production was HBO's Deadwood; An Klondike's director Dathaí Keane has recalled watching a scene from David Milch's acclaimed Western series where two men are in a saloon and speaking Irish to each other and being struck by how "Irish people travelled abroad and could easily have been speaking Irish in the Wild West and it made me think "where else could they have been speaking Irish"?" (Keane quoted in Brosnan 2015). Language is an important aspect of Keane's production, with most of the leading cast native speakers, and the series includes several moments where the use of Irish is commented directly upon - including one particularly humorous scene where one of the leads, Tom Connelly (Owen McDonnell, a native speaker), offers to ram the teeth of the local Irish enforcer Galvin (Ned Dennehy, clearly a nonnative speaker of Irish) down his throat in the hope it may improve his Irish language skills.

The focus of the film, however, is primarily on the experiences of three Connolly brothers: the eldest and most ambitious Tom (Owen McDonnell in a role very reminiscent of the character he played in PJ Dillon's excellent short An Ranger (2008)), the deeply religious Pádraig (Dara Devaney), and the youngest and feckless Séamus (Seán T. Ó Meallaigh), all of whom travel from Montana to the Yukon in search of their fortune. Their initial decision to do so is inspired by a family friend who gifts them a claim along with a cryptic Native American map that may lead to its location (if they could only read it). However, before they can set out, Séamus steals the map and claim and heads off alone, only to sell it to the local saloon manager, JJ Hopkins (Ian Toner) in return for gambling money. When his brothers catch up with Séamus, Hopkins offers Tom the chance to earn back the claim by fighting a Native American, Skookum Jim. After regaining the claim and mysterious map (and befriending Skookum Jim), Jim helps Tom to decipher it, leading the brothers to their claim. However, finding the claim brings further conflict among the brothers and with the locals, particularly after the arrival of Hopkins' father, Jacob (brilliantly played by Robert O'Mahoney), the real power in the town who goes to considerable lengths to undermine and destroy the Connollys after Séamus kills his son in a duel. In all of this the film repeatedly reveals the harsh reality that lay beneath the much mythologised 'American Dream' that attracted many of the thousands of Irish emigrants to the Klondike.

The producers of An Klondike manage to create a convincing portrayal of the time and place, assisted considerably by the excellent production design of Padraig O'Neill and the evocative musical accompaniment composed by Steve Lynch, who drew on many instruments that would have been heard in the Klondike region during the Gold Rush. Setting many of the series' scenes in the local saloon also offered the opportunity for regular live musical performances, particularly by the excellent Siobhán O'Kelly as Kate Mulryan, a love interest for both the local Mountie Steele and Séamus Connolly. The convincing realisation of time and place is all the more impressive as Klondike was entirely shot in Conamara on the very modest budget of $€ 1.8$ million; the town of Dominion Creek was built on a site next to the Glengowla mines (where the mining scenes were shot), near the town of Oughterard. While the landscapes of Conamara and the Klondike share considerable similarities, the extent to which O'Neill and his production design crew went to create this late $19^{\text {th }}$ century Canadian town is impressive; research 
was carried out in the Dawson City Historical Conservation Society who advised on the architectural details of each building depicted in the series including features such as doors, windows, cornices, and balconies.

An Klondike does have its flaws and the transition from series to feature film is not wholly successful, particularly given the at times convoluted nature of the series' many subplots. Pádraig's role in particular is underwritten and his relationship with Father Judge and the priest's attempts to establish a local church and hospital would have benefited from more develop- ment. However, the series as a whole offers a convincing and engaging rendering of the period in question. What is more, An Klondike is also revealing regarding the place, position, and ambition of Irish language film and television production today. It speaks to the huge advances made in this area since the advent of TG4 (initially TnaG) in 1996 - advances charted in previous articles in this journal including last year's review of Tom Collins An Bronntanas (The Gift) - and provides yet a further reimagining of one of cinema's most significant genres.

\section{Works Cited}

Brosnan, Seán. 2015. "Interview with An Klondike director Dathaí Keane”, Irish Film and Television Network, 7 September, http://www.iftn.ie/news/?act1=record\&only=1\&aid=73\&rid=4288590\&tpl=archnews\&force=1

Buscombe, Edward (ed.). 1988. The BFI Companion to the Western. London: André Deutsch/BFI Publishing.

Byrne, James P. 2009. "Ethnic Revenge: A Structural Analysis of the Western Tropes of Twentieth Century IrishAmerican Assimilation”. In Seán Crosson and Rod Stoneman (eds.), The Quiet Man ... and Beyond: Reflections on a Classic Film, John Ford, and Ireland. Dublin: Liffey Press, 30-41.

Faraci, Derek. 2016. "How Green Was My Movie? THE QUIET MAN Is A True Western", birthmoviesdeath.com, 8 January. http://birthmoviesdeath.com/2016/01/08/how-green-was-my-movie-the-quiet-man-is-a-true-western

Kollin, Susan. 2007. "Introduction: Postwestern Studies, Dead or Alive" in Postwestern Cultures: Literature, Theory, Space, by Susan Kollin. Lincoln: University of Nebraska Press, ix-xix.

Stacey, Pat. 2015. "Why you need to watch new Irish western An Klondike", Evening Herald, 8 September. http://www.herald.ie/entertainment/tv-radio/why-you-need-to-watch-new-irish-western-an-klondike31510299.html

Seán Crosson lectures at the Huston School of Film and Digital Media, NUI Galway where he is director of the MA Film Studies programme. His most recent publications include (as Co-editor with Werner Huber), Towards 2016: 1916 and Irish Literature, Culture \& Society (Irish Studies in Europe, Volume 6) (Wissenschaftlicher Verlag Trier, 2015). 


\section{Sentimentality and "Difficult" Art in Room (Lenny Abrahamson 2015)}

Eileen Culloty

In The Unbearable Lightness of Being (1984), Milan Kundera writes that sentimentality or kitsch "causes two tears to flow in quick succession. The first tear says: How nice to see children running on the grass! The second tear says: How nice to be moved, together with all mankind, by children running on the grass". Kundera's biting observation is twofold: he takes aim at artistic short-cuts to emotional engagement, such as those relying on the innocence of children, and at the viewers who bask in their own capacity for feeling. Oscar Wilde expressed this idea more pithily as "the luxury of having an emotion without paying for it".

From the late $18^{\text {th }}$ century onwards, seriousminded critics have used sentimentality as a term of abuse to dismiss the emotionality of popular art. More recently, a number of writers have defended sentimentality as an important category of emotional engagement. The philosopher Robert Solomon, for example, persuasively argues that sentimentality promotes the kind of emotional sensitivity that is essential to expanding our capacity for empathy with others.

Kundera and Solomon are both right about sentimentality; it can be cheap and it can be enriching. Unfortunately, Lenny Abrahamson's Room has more in common with Kundera's tears than Solomon's emotional sensitivity. It falls into a specific category of "Oscar bait" that is well acted and superficially heavy. Like the treatment of AIDS in Dallas Buyers Club (2013) or racism in Crash (2004), Room takes a weighty subject the victims of a sexual predator - and creates a work of lightly redemptive cinema.

1. Robert C. Solomon, In Defense of Sentimentality, Oxford University Press, 2004.
Serious films do not have to be achingly philosophical or unrelentingly bleak. Yet, Room's pursuit of cuteness and sentimental redemption means glossing over the more difficult elements of the story. This is a questionable pursuit given the horrific nature of the storyline: A young woman Joy (Brie Larson) is abducted and kept as a sex-slave in a small room where she raises Jack (Jacob Tremblay), the child of her captor, for five years until they escape and return to her family.

Adapted by Emma O'Donoghue from her own novel, which was inspired by the Josef Fritzl case, Room is awkwardly translated to film. The central conceit of restricting the narration to Jack's perspective is only partially maintained through a naively-wise voice-over. Plot lines involving other characters are hinted at but under-developed because they are beyond Jack's perspective. Yet, the film isn't really from Jack's perspective either. He is very much an object of innocence to be gazed at rather than a developing mind through whose prism we can view the strange new world.

It's interesting to think what might have resulted had the film fully committed to the child's perspective in the manner of Ponette (1996) or Cría Cuervos/Raise Ravens (1976). Through an extraordinary performance by Victoire Thivisol, four year old Ponette negotiates complex thoughts about death and theology as she tries to summon her mother back to life. Throughout, her growing thoughtfulness about the world is credibly born of anguish and confusion. Similarly, Raise Ravens draws us into the world of an isolated child who sometimes understands too much and sometimes misunderstands what she sees. The child here is innocent but this innocence is also threatening; the title refers to a Spanish proverb "raise ravens

ISSN 1699-311X 
and they will pluck out your eyes". Apart from a tantrum in Room, Jack is not afforded any such mental nuance. He is a safe adult fantasy about the resilience of children; a symbolic conduit for sentimentality.

Structurally, Room is definitively divided into two parts: a study of confinement in room and a study of adjustment in the outside world. In transitioning to part two, the film briefly echoes a suspense thriller as Jack escapes and then rescues his mother via an improbable scene with two suburban cops.

Stylistically and thematically, the film is most interesting in part one. Much like Roberto Benigni in Life Is Beautiful (1997), Joy is resourceful in shielding her son from the awfulness of their situation and her emotional state convincingly moves between frustration, resignation and desperation. The camera remains within the room throughout but Abrahamson uses a soft background focus and elevated angles to conceal the true scale of the room. He thereby cleverly creates the impression of a confined space made larger with Jack's imagination.

Part two is where the film begins to unravel. It vacillates between Jack's adjustment to a new world and his mother's struggle to reintegrate. In the novel, Joy continues to breast-feed Jack after they have escaped, which is a source of contention among her family and doctors and partially accounts for the bullying nature of the TV interviewer. With the breastfeeding plotline reduced to brief references, the aggressive TV interview becomes a contrived device to instigate Joy's suicide attempt and take her out of the story.

With Joy in hospital, we watch the wise and accepting grandmother (Joan Allen) take charge in bringing normality to Jack's life. Abrahamson tugs easy heart-strings by showing Jack's late introduction to the ordinary delights of childhood like ice-cream, the pet dog and a new play friend. These scenes invite us to think "how awful" and "how sweet": how awful that Jack was denied the joys of childhood but how sweet that he has found them now. This is where Kundera's second tear starts to flow. When his grandmother cuts his hair for the first-time in his life prompting a breakthrough "I love you" from
Jack - the family redemption story is nearly complete.

The film is replete with heavy-handed symbolism. In one scene, Jack is framed peering through the balustrade of his grandmother's house as though trapped in his new-found freedom. This isolated image is impactful but doesn't relate to the wider narrative in any meaningful way. The direction frequently calls on melodramatic TV tropes including slowmotion effects to signpost emotional intensity. Meanwhile, the dialogue is often mawkish as when Jack's grandmother greets him for the first time by gushing "thanks for saving our little girl". This is the film's big idea: Jack is the saviour of Joy.

Given the extent of their trauma, Joy's middleclass family are strangely ordinary. Her father does struggle to separate his grandson from the rape of his daughter but he is quickly disappeared from the film along with his complex emotions. The inevitable motherdaughter confrontation scene - "you've no idea what's going on in my head", "you blame me" plays out like a stereotypical teen-parent rift. They could be arguing about anything.

Jack himself is strangely ordinary. Even allowing for the remarkable plasticity of children, it's hard to accept that there is no damage to the psychological development of a child who has been locked in a tiny room and surrounded by sexual abuse for his entire existence. Jack's development is reduced to finding names for toys and bonding with Seamus the dog. It is this trivialisation of abuse and recovery as a simplistic "journey" to love that borders on the insulting. Naturally, the self-help journey to redemption is complete when Joy and Jack make peace with their old prison and say "goodbye" to "Room".

Consider Spotlight (2015) as another one of this year's Oscar worthy films addressing sexual abuse. Unlike Room, Spotlight takes a step back from the abuse to focus on the complicit blindness of a tightly-bound Boston society. The devastating consequences for the victims are only touched on in a few short scenes. Yet, we are never left in any doubt that sexual abuse creates mentally broken individuals prone to 
addiction, self-harm and suicide. Room puts the victims centre-stage but there is little insight into human suffering beyond the most basic empathy for an awful situation.

This basic empathy may partially explain why popular reviews of Room are overwhelmingly positive. It feels heartless to criticise a film about such a difficult subject. Critics find it equally difficult to criticise well-intentioned 'progressive' films about war and genocide. Much like Danis Tanović's awards laden No Man's Land (2001) - a Bosnia set anti-war film - or even the Spielbergian take on Thomas Keneally's "Schindlers's Ark", the appeal of Room is that it makes a challenging subject palatable and applauds the viewer for her compassion.

To paraphrase Wilde, Room offers Hollywood the luxury of a difficult art film without the emotional strain. For Abrahamson, this is perhaps the point. He has already established his art-film credentials; in particular, with the character study of rural isolation in Garage (2007) and the uplifting portrayal of eccentricity in Frank (2007). Room is a calling-card to Hollywood.

Martin Scorsese has described his Hollywood career as a balance between making "one for them and one for me" whereby a mainstream studio film like The Colour of Money (1986) is followed with a more risky and personal film like The Last Temptation of Christ (1988). Room might best be remembered as the means by which Abrahamson got himself into the privileged position to make such strategic decisions.

Eileen Culloty is Associate Researcher at the Institute for Future Media and Journalism and a lecturer in the Department of Communications, Dublin City University, Ireland. 


\section{Queen of Ireland (Conor Horgan 2015)}

Debbie Ging

Like Panti herself, a self-declared 'accidental activist', Conor Horgan's The Queen of Ireland was partly shaped by the serendipitous coalescence of certain events. When Horgan began filming in 2010, he could not have foreseen Rory O'Neill's legal row with the public broadcaster, Panti's Noble Call speech in the Abbey Theatre or Ireland's resounding yes vote in the 2015 marriage referendum, all emotionally charged events that would provide him with a dramatic and deeply affective 'third act'. Yet, while there is no doubt that the stars aligned in mysterious ways to produce the unexpected and wonderful story that is The Queen of Ireland, this documentary is also the product of meticulous archival research, a keen awareness of the importance of queer history and a deeply held humanist sensibility. Similarly, Panti's trajectory from drag queen in Japan to prominent LGBT spokesperson is not merely a tale of happenstance but also a journey shaped by the synthesis of creativity, intellectual curiosity, political activism and hard work. Horgan's outstanding achievement - like Panti's - is that he has successfully drawn together the political, the personal and the performative in a way that demonstrates how drag can function as a potent agent of social change.

In 1968, the year of Rory O'Neill's birth, a documentary called The Queen was released in America. It was a behind-the-scenes insight into a New York drag-queen contest, and it divided the critics, some of whom welcomed it as a sympathetic exposé of the real people behind the caricatures, while others feared that it would do the gay rights movement more harm than good by playing into "flaming queen" stereotypes (Luther Hillman 2011). Drag has long been a central presence in gay culture and politics: drag queens and street queens featured heavily in the 1969 Stonewall rebellion in New York, and have been central to Gay Pride marches all over the world since the 1970s. As Judith Butler has commented, drag is, by its nature, both gendertransgressive and progressive, not only because it highlights the fact that all gender is performance but also because it exposes "the failure of heterosexual regimes ever fully to legislate or contain their own ideals" (Butler 1993: 26). But drag has also been a contested and divisive issue in LGBT politics. As Luther Hillman (2011: 158) notes:

While some liberationists appropriated drag as a symbolic statement against gender norms, others saw drag as exacerbating stereotypes of 'effeminate' homosexuality. Still others aligned with radical feminists who saw female impersonation and drag as an affront to women, reinforcing cultural stereotypes of femininity. These debates coalesced into contradictory stances on the political and cultural meanings of drag and drag queens as constituents of gay liberation.

Almost 50 years later, when the prospect of a referendum in Ireland on marriage equality finally came into view, a not entirely different set of tensions emerged in debates within the LGBT community. Those with more conservative leanings readily embraced the idea of marriage, while more radical queer activists feared that conforming to an outmoded, patriarchal institution such as marriage and its attendant investment in procreation, monogamy and the nuclear family would reduce and restrict the possibility of more fluid understandings and articulations of gender, sexuality and the family. Why would anyone want to assimilate a restrictive set of ideals and constructs into queer culture, they - rightly - asked. But besides the

ISSN 1699-311X 
practical issues that were at stake regarding people's rights in relation to children, property inheritance and next-of-kin arrangements, this was seen by almost everyone as a basic human rights issue. And so even those who were ideologically opposed to the institution of marriage got behind the campaign because there was growing consensus that it was, first and foremost, about recognizing all of Ireland's citizens as equal. LGBT people and their allies, whether they were monogamous, Fine Gaelvoting Christians or anarchist, polyamorous BDSMers, understood that persuading the electorate to vote yes would require empathy as its key strategy as well as a certain degree of convincing the nation's more conservative citizens that LGBT people were the same as everyone else.

One could have been forgiven, therefore, for thinking that transgressive, "flaming queen" queerness might not cut it with the crucial swathe of Middle Ireland who were undecided, and who were ultimately going to swing the vote. Except somehow it did. This is Panti's most remarkable achievement, and the power of Horgan's documentary lies precisely in its subtle exploration of how Rory O'Neill's "giant cartoon woman" alter ego succeeded in getting an older, more traditional Ireland on the side of marriage equality. Clearly, the marriage equality campaign was not championed by Panti alone it was the result of many years hard work by hundreds of committed activists - but the fact that a glamorous and outspoken drag queen became its key figurehead is remarkable. O'Neill has lived a remarkable life through remarkable times: born in the year of the student riots in Paris, he embodies Ireland's transformation from a conservative, Catholic state to a modern, secularizing nation. From the murder of Declan Flynn in 1982 through the emergence of HIV and AIDS to Dublin's burgeoning queer club scene in the 1990s, the decriminalization of homosexuality in 1993 and, finally, marriage equality, Horgan presents a concise but colourful and insightful history of LGBT rights in Ireland through the prism of O'Neill's life as a performer and activist. O’Neill narrates much of this story in interview and narrative voiceover, allowing us an insight into the intellect, selfreflexivity and humour that have given rise tothe more flamboyant persona that is Panti. As O'Neill comments, Panti allows him to play the role of the clown, the fool, the court jester; to say the unsayable.

Crucially, both Panti and Horgan's documentary refuse to play into obvious homonormative strategies of tolerance and acceptance. The documentary's unapologetic celebration of gay life and culture includes stills of risqué nightclub posters from the HAM and GAG club days as well as an anecdote about a fetish club performance in which a string of pearls was secreted in - and ceremoniously removed from - "Panti's person". These images and segments sit alongside photos from O'Neill's 1970s childhood and postcard-type shots of his hometown of Ballinrobe, not to create a montage of striking juxtapositions but rather to imply that these experiences of Ireland are now oddly compatible and harmonious. The glue between the personal and the political, and between Ireland's rural past and modern present is most effectively rendered, however, through the sparse but powerful presence of O'Neill's parents throughout this story. Open, warm and unassuming, they are impressively unfazed by the drama that their "fourth daughter" has brought into their lives. O'Neill's is not a conventional coming out narrative of struggle and eventual coming to terms, therefore, since his parents recognised and accepted his difference from the outset. Over a montage of photos of his early childhood, his smiling mother proudly comments, "He's his own man". When O'Neill speaks candidly about discovering he was HIV-positive in 1995, his father talks about how he prayed to Jesus for a solution. However, it is not conventional Catholicism but rather their understated humanism that makes O'Neill's parents such compelling and inspiring characters in this story.

It is this same humanism that is at the heart of Panti's potent balance of humour, political activism and righteous anger, and the shows that O'Neill has been doing since 2007, such as In These 
Shoes, All Dolled Up and High Heels in Low Places, are testimony to the political and affective power of drag. Beneath the ribald anecdotes and self-effacing humour lies a sophisticated theorisation of gender and sexuality. Panti is exceptionally clear about why she dresses as a woman and what it means: she is not pretending to be a woman, nor is she celebrating or appropriating stereotypical (hyper) femininity - she is lampooning the extreme rigidity of gender roles and is using that performative space to expose gender as a cultural code that relies on mimicry and cultural reinforcement, just as drag kings lampoon hypermasculinity by performing as soldiers and sailors. She is conversant with intersectional politics, and sensitive to both the achievements and limitations of second-wave feminism. In this sense, Panti is something of a Trojan Horse, smuggling serious gender-political analysis and queer politics into popular forums in the guise of entertainment, always with a well-measured dose of righteous anger. This becomes especially evident in the marriage referendum segment of the film, when she addresses the crowd at a postPride rally as follows: "Any asshole can get married but not you. Any dumbfuck soccer hooligan can get married. Any gay basher on Georges Street at 4am can get married. Any fascist, any murderer, any sex offender can get married. But you cannot...you should be angry about that".

The Queen of Ireland reaches its emotional crescendo in the unfurling of those extraordinary events that preceded the referendum - Pantigate, the outstanding Noble Call speech in the Abbey a show for O'Neill's mother, this performance theatre and the heady reaction it provoked when it went viral, with supportive tweets sent from Madonna, Martina Navratilova, Stephen Fry, Boy George and $\mathrm{Ru}$ Paul - culminating in the victorious day itself. Seeing the footage of Dublin Castle on the $23^{\text {rd }}$ of May is deeply moving, and it is impossible to imagine anyone watching these scenes without crying. But it is the documentary's final segment - Panti's return to Ballinrobe to perform in a marquee erected in the car park of the local tyre business - that provides the film's real tear-jerker finale. Conceived of as serves as the ultimate narrative reconciliation of queer culture with small-town, rural Ireland. Panti's walk from the family home to the marquee, flanked by her parents wearing rain jackets and carrying umbrellas, calls to mind (a peculiarly Irish twist on) Mike Silverstein's comment about the revolutionary power of drag:

\begin{abstract}
When a Street Queen walks down the street, she's a one-person rebellion, her being an affront and attack on the straight world around her...The Street Queen denies the reality of the whole structure of Masculine-Feminine roles. She refuses to be either a man or a woman, and that is the most profoundly revolutionary act a homosexual can engage in (Silverstein1970, cited in Luther Hillman 2011).
\end{abstract}

The final scenes, in which O'Neill's parents laugh hysterically at in-jokes about a local character called Cock Jennings are overlaid with the film's moving original score, and serve as a poignant affirmation that the world can be changed in astonishing and unexpected ways.

\section{Works Cited}

Butler, Judith. 1993. "Critically Queer”, GLQ: A Journal of Lesbian and Gay Studies 1(1). 17-32.

Luther Hillman, Betty. 2011. “The most profoundly revolutionary act a homosexual can engage in': Drag and the Politics of Gender Presentation in the San Francisco Gay Liberation Movement, 1964 1972", Journal of the History of Sexuality 20(1). 153-81.

Silverstein, Mike. 1970. "god save the queen', Gay Sunshine 1(3). 2.

Dr. Debbie Ging is a lecturer in the School of Communications, Dublin City University. Her research focuses on all aspects of gender and sexuality in the media and, in particular, on masculinity in film. She is co-editor of Transforming Ireland: Challenges, Critiques, Resources (Manchester University Press 2009) and author of Men and Masculinities in Irish Cinema (Palgrave Macmillan 2012). 


\title{
Performance of Myth: The Legend of Longwood (Lisa Mulcahy 2014)
}

\author{
Loretta Goff
}

The Legend of Longwood, situated in the realm of family adventure film, is one of a number of recent Irish films, including Pursuit (2015) and Song of the Sea (2014) to feature the use of myth prominently. The film follows twelve year old Mickey Miller, her mother, and younger brother as they move from New York to the fictional Irish village of Longwood after inheriting a home there. Mickey's arrival coincides with the return of the legendary Black Knight. Once a prominent and kind man living in the Dumonceau castle, after his baby daughter was kidnapped he became angry and bitter, working the villagers too hard and starving them in a manner reminiscent of Famine Era Ireland. On the night of a tragic fire that killed seven village children, the Knight mysteriously disappeared and was believed dead. Since then, the village has been cursed by the Black Knight who continues his search for his daughter. While the employment of the myth in this film will satisfy the film's younger viewers (and intended audience) with its fantastical elements, it raises different points for older viewers with economically-driven subplots, performative undertones, and questions of identity.

Unlike the established Irish mythology used in Song of the Sea or Pursuit, the mythical story in The Legend of Longwood originated in the Netherlands, with the screenplay by Nadadja Kemper, and was then rewritten by director Lisa Mulcahy (Red Rock, The Clinic) for the Irish setting. This hybridisation speaks to the film's international co-production and financing: Grand Pictures (Ireland), Holland Harbour (the Netherlands), and Longwood Pictures (Germany), produced the film and it was funded by the Irish Film Board, the Dutch Film Fund, Premiere Pictures, and the German Federal Film Fund. This mixture of funding, the fact that the film was shot primarily in Wicklow and Dublin, and the plot which centres on an American heroine, all bear influence on the film and are reflected in its distribution to date. After premiering in July 2014 at the $44^{\text {th }}$ Giffoni Film Festival in Italy, The Legend of Longwood continued to play on the Festival circuit in Europe and, in 2015, was released on DVD in the US and Canada, and theatrically in Germany, Ireland and the UK. The clear links between the film's funding, casting, narrative and the locations of its distribution, speak to the ways in which economic factors play a large role in how films are constructed. The topic of economic incentive also features prominently within this film, and is critiqued.

The employment of myth in The Legend of Longwood acts, in two separate ways, to place Ireland in an international context. The first of these focuse on money and the second on identity. Early on in the film we are introduced to the commodification of Longwood, and its myth, in the village library. Here, we see a poster advertising the sights of Longwood as well as a rack of postcards for sale. As the librarian discusses having seen the Black Knight recently, the Mayor picks up a postcard featuring the Knight, highlighting the degree to which the legend has become a product. This postcard sparks an idea for further revenue, and the Mayor schemes up a way to draw more visitors to the village. He enlists the help of a newspaperman to perform the myth and then write an article on it. After the "Knight" makes an appearance at the village's very public inaugural car rally and word spreads, the Mayor hopes that the intrigue of the legend will put the village on the map. Though he does not believe in the legend himself, the Mayor is more than happy to sell a performance of it. While hatching the plan, he says: "There is no Black Knight. But then, the tourists don't know that."This statement, overtly referencing tourists (and how to fool them), brings to mind Ireland's own strong economic links with tourism. A recently published report by Fáilte Ireland detailing 
overseas tourism to Ireland in 2014 , notes an overall growth of $6 \%$, bringing in 7.1 million visitors who spent an estimated $€ 5.1$ billion in the country (Tourism Facts 20142). The impact this has in Ireland is made clear by the fact that $24.5 \mathrm{c}$ is generated in tax for every euro spent on tourism and 34 tourism jobs are supported by every $€ 1$ million of tourist expenditure (4). Additionally, "because tourism is characterised by the fact that consumption takes place where the service is available and tourism is frequently concentrated in areas which lack an intensive industry base, it is credited with having a significant regional distributive effect" (2). Bearing these facts in mind, the Mayor's plan to revitalise his village in The Legend of Longwood does not seem outlandish, even if he does have to create a performance to do it. After all, so too are most tourism campaigns, along with the performances of traditional music and dance (and myths of leprechauns) that bring tourists to Ireland.

Unfortunately, the Mayor's plan to "save" Longwood is ultimately an expression of his own greed. His character is set up as one of the "bad guys" in the film, aligned with Caitlin Lemon, who will stop at nothing to marry the wealthy Earl, Marc Dumonceau (descendant of the Black Knight), in order to raise her own status and riches (her mother used to clean the Dumonceau castle which Caitlin now seeks to inherit). The excessively materialistic, status-driven attitudes of these two characters, and their snobby children, are reminiscent of the excesses of Celtic Tiger Ireland. Their self-indulgence sees them hatch plans of questionable morality together in order to reach their respective goals; Caitlin plans to sell the Dumonceau lands to the Mayor for $€ 2$ million so he can create a golf course to personally benefit from tourism revenue and she can transform the castle into a modern mansion, complete with tennis courts and pools.

The fact that these two characters are portrayed as conniving, willing to break the law, and cause harm to others, in the pursuit of their capitalistic desires, illustrates the potentially negative impacts of tourism. It is here shown as a greedy endeavour by a few individuals that would harm the town's culture and history, particularly evident through the plans to modernise and commercialise the historic Dumonceau castle and grounds. This characterisation of tourism (development plans) as "bad" and capitalistic in the film is similarly found in other films with Americans travelling to Ireland, particularly The Matchmaker (1997), Irish Jam (2006), and Honeymoom for One (2011). As is the case in all of these films, the "good" locals ultimately win, preserving their community with the help of the American who has become a part of it. Just as the Celtic Tiger went bust, so too does the greed of Caitlin and the Mayor backfire in The Legend of Longwood as their plans are foiled by Mickey. This negative portrayal of tourism falls in line with the binary typically found in Irish tourism research wherein "either tourism is seen as a 'Good Thing' which brings in money, creates jobs and facilitates regional development or it is seen as intrusive, exploitative and uniquely destructive in its commodification of peoples and their cultures" (Cronin and O'Connor 3). Though the Mayor's utilisation of the myth to drive tourism in Longwood is has the potential to benefit the village, the way he and Caitlin are positioned in opposition to the film's heroine, their greed, and the questionable methods they use in their endeavours, ultimately paint tourism as both exploitative and destructive, rather than allowing for a middle ground.

Meanwhile, Mickey's involvement with the myth, and her own plan to save Longwood by breaking the curse, creates positive personal growth for her character, broadening her perspective and reconfiguring her identity. Upon first learning of her family's sudden move from New York to Ireland, Mickey is upset and does not want to go. Her mother tells her "it's Ireland, not the end of the world". However, upon arriving at their new (run-down) home in Longwood during a cold, grey day, Mickey calls it just that, and has no interest in being there. Told this is their home now, Mickey claims that "this will never be home", a sentiment that is visually reinforced moments later with a broken "Home Sweet Home" flowerpot. Mickey is thus initially set up in opposition to Ireland, hoping to return to New York. However, things soon change 
as she becomes involved with the legend of the Black Knight. Mickey befriends her classmate Sean, whose help she enlists in breaking the curse, and Lady Thyrza Dumonceau, who explains the legend to her. These friendships act as the first connections to her new life, wearing down her oppositions. Thyrza also introduces Mickey to seven white horses tied to the legend that appeared on the castle grounds after the death of the seven children. Mickey's love for horses, and the reminder of her old horse in New York, immediately connects her to them, and further draws her into the legend and her new life.

The more Mickey investigates the more her links to the tale become evident, and she reevaluates her own identity. We learn that Mickey's father, an archaeologist who has been missing for years (presumed dead), was from Ireland, and Mickey begins to relate to this side of her identity, previously left largely unexplored. After Thyrza suddenly turns up dead and Mickey has visions of the Black Knight, with Thyrza telling her to break the curse, she seeks Sean's help. Not believing Mickey's visions he exclaims: "you Americans, you come here and see ghosts [...] What's next, leprechauns?" This once again separates Mickey from Ireland, labelling her as American (or foreign). It simultaneously brings attention back to the tales told to draw in tourists, commodified myths. However, after now having lived in the village, Mickey takes a new stance, telling Sean: "My father is Irish, so technically I'm only half American." With this statement, Mickey firmly establishes her identity as Irish-American, rather than simply American, and, at the same time, now professes to have a more intricate knowledge of, and connection to, Ireland than an average American. Now that she lives there, her sense of connection has shifted and she reduces her identification with America to half, illustrating the protean nature of identity. The direct measurement (and hyphenation) of her identity reveals the choice and shifting balance of identification involved in forming it.

Mickey is still referred to as a "Yank" in the film by classmates, and, as she and Sean work out how to break the curse they award points to
"Ireland" or "America" based on who figures it out. Therefore, she is still set up as American, and ultimately an outsider, in Ireland. Despite claiming her Irish side,

Mickey is still from America. She also faces the possibility of returning to America after her investigation of the legend results in confrontations with Caitlin who files a lawsuit, leading Mickey's mom to decide to move back to New York. Despite originally wanting to return, both Mickey and her brother are now determined to stay in Ireland, their new home. This again illustrates the major shift in Mickey's identification. As her perception changes, Mickey's Irish connection is revealed to be even deeper. The amulet she wears (a gift from her father) is connected to the curse, and needed to break it, along with a song he sung to her as a child. As she discovers these links, Mickey also uncovers the fact that the Black Knight's daughter survived, adopted by the family who ran the mill, and that she, herself, is a direct descendant of them both. Not only does this mean Mickey is perfectly suited to break the curse and save Longwood, it also provides her with historic, deeply embedded roots in the village. This draws comparison to many other Irish-Americans whose relatives left Ireland generations ago, but Mickey's experience is made more unique by the myth which not only gives her a specific purpose and role in Longwood, but also allows her to interact with her ancestors as the legend essentially brings them to life, connecting her to Ireland in both an historical and contemporary sense.

Ultimately, the use of myth in The Legend of Longwood drives more than the narrative of the film. As Barry Keith Grant points out, "whether they are set in the past or in the future, on the mean streets of a contemporary New York or long ago in a galaxy far away, genre movies are always about the time and place in which they are made" (6). The decision to perform the legend of the Black Knight to entice tourists in the film directly references Ireland's own tourism industry, wherein various "performances" are sold to tourists. Practices of tourism that tarnish history are simultaneously critiqued here by revealing the Mayor's greed and placing 
him (and his plans for the village) on the "bad" side. At the same time, the myth casts Mickey as a heroine, and affects her own performance of identity. Acting at a more personal level, Longwood's legend becomes Mickey's own as she confronts her family's past and transforms from a homesick American to an Irish-American at home in Ireland (albeit still considered American). In its application to Irish tourism and diasporic identification, the performance of the. myth in The Legend of Longwood ultimately links directly with certain Irish realities. The international nature of these, and the collaboration involved in producing the film, similarly speaks to the reality of an increasingly globalised, migratory world which continues to shape both identity and film

\section{Works Cited}

Cronin, Michael and Barbara O'Connor (eds.). 2003. Irish Tourism: Image, Culture and Identity. Clevedon: Channel View Publications.

Grant, Barry Keith. 2007. Film Genre: From Iconography to Ideology. London: Wallflower Press.

Tourism Facts 2014. 2015. Dublin: Fáilte Ireland, October 2015 [Web accessed on 30 December 2015].

Loretta Goff is a PhD in Film and Screen Media candidate at University College Cork, Ireland. 


\section{My Bonnie (Hannah Quinn 2015)}

Isabelle le Corff

My Bonnie is the directorial debut of Hannah Quinn, a member of the talented Quinn family which includes her film-making father Bob and brother Robert, and who has worked for over 20 years as an assistant director on numerous film productions. The story was adapted from the Tiny Play Sanctuary written by Liz Quinn and first performed by Fishamble Theatre Company in 2012. As a reminder of Bob Quinn's films, it is made entirely by a west of Ireland crew and set very deliberately in Conamara.

Shot on location by gifted Irish cinematographer Tim Fleming (Once, As if I'm not there, Gold, the film opens on a peaceful blue seascape. A pan to the left reveals the slim figure of a woman sitting on a rock facing the rising sun. In the next shot, Sadie (Liz Quinn) is seen in midshot, humming the old ballad "My Bonnie Lies over the Ocean". The discontinuity of the shots, the contrast between the first open, unobtrusive composition and the following close-shot raises the question of the right distance from which to look. On the last note the woman rattles some pebbles in her hands, making a sound like applause. Her imagined audience - we - are thus made complicit in Sadie's triumph, as she gets excited, acknowledging our demand for an encore.

A wide shot immediately reminds us that Sadie is perfectly alone on the beach and giving free rein to her imagination. The spectator is consequently made intrusive in the same way as a second character, who appears at the extreme left-hand corner of the long shot, just as she twirls and collapses ungracefully into the shallow water. The man has witnessed her moment of embarrassment. She is outraged and storms away.

At this stage the spectator may believe that the meeting between the two characters is fortuitous, but the connection between them increasingly becomes transparent. The eye-level shot on the couple climbing the rocks, Sadie trying to get away and Dan (Tom Sullivan) attempting to reach her, epitomizes their conflicting relationship. As we are gradually made aware of their familiarity, the couple appears to be trapped on a rock that resembles a whale at high tide. Without any possible escape, they have to confront the distance that has grown between them. Dan is appeasing but she is obdurate. Every exchange between the two suggests failure. "There's plenty of space on this beach you know", she tells him, and he obstinately replies, "I know, it's great"; "You're never more than six feet from a rat", he says, "You don't say", she ironically answers. He offers breakfast; she refuses, screams that she "hates fucking black pudding", something he had obviously never realized in all the years he has lived with her. She intends to leave him. As they keep arguing, several long shots reveal the two characters, sometimes close and sometimes far from each other on the majestic Carraig Leathan rock. But either way, they are surrounded by water, and they cannot run away from each other. She denies she is "the rat deserting the sinking ship", the rock is steady and "he will be fine". As the day passes, they gradually dig up warmer memories - as through the device of an underwater shot. When at sunset they admit their relationship with each other, the statements "I hate you" "I hate you too" clearly mean that, despite all, they are still inextricably and lovingly involved.

That catharsis is a lot to attempt in a short film but My Bonnie succeeds in achieving it. The use of a spectacular location (Carraroe, Conamara) perfectly fits with the storyline, and music by the Americana folk duo "Hidden Highways" beauti-

1. https://hiddenhighways.bandcamp.com/album/ hidden-highways-ep

ISSN 1699-311X 
fully concludes the narrative. The difficulty of the couple on the rock to be together or split, find the right distance, epitomizes every human relationship, and may well symbolize Northern Ireland and Eire in their struggle to love and hate each other or be fine separately together.

The film was premiered at the Newport Beach film festival, California in April 2015, where it won the honour of "Outstanding Achievement in Filmmaking".

It then won the "Donal Gilligan award for Best Cinematography" at the Galway Film Fleadh and "Best Irish Narrative Short". It has screened successfully at numerous international film festivals since.

Isabelle le Corff is Maître de conferences in Anglais et Cinéma, Université de Bretagne Occidentale, Brest. 


\section{A Revision of the Family in Irish Film: Glassland (Gerard Barrett 2015)}

\section{Deirdre Molumby}

Having garnered critical praise and a number of awards for his first feature, Gerard Barrett follows Pilgrim Hill (reviewed in Estudios Irlandeses No. 9) ${ }^{1}$ with Glassland. While the earlier film focused on a lonely dairy farmer who cares for his critically ill father, Glassland moves to the urban setting of Dublin while continuing the director's thematic exploration of isolated Irish men who struggle with contemporary Irish life. Jack Reynor plays a young taxi driver who struggles daily to make ends meet and keep those around him safe and happy. His mother Jean (Toni Colette) is an alcoholic who refuses to see her son, John's brother, Kit (Harry Nagle), who has Down syndrome and has been placed into a care facility. John's best friend, Shane (Will Poulter), will soon be emigrating, leaving John on his own to piece together his broken family and to help his mother face her addiction head on. Glassland contributes to the Irish film canon by way of its revision of the Irish family, rewriting figures such as the "Irish mammy" and "Irish lad" and through its exploration of the theme of alcoholism.

The "Irish mammy" is a dominant figure that has persistently appeared in popular culture produced by and about Ireland. Exemplified by Brenda Fricker in My Left Foot (Jim Sheridan, 1989) and The Field (Jim Sheridan 1991), the type continues to appear in pop culture today in many forms including advertising ${ }^{2}$ and the hit

1. Laura Canning, "Pilgrim Hill (Gerard Barrett 2012)", Estudios Irlandeses 9, 2014, 218-20.

2. Diane Negra, "Adjusting Men and Abiding Mammies: Gendering the Recession in Ireland", in Masculinity and Irish Popular Culture: Tiger's Tales, ed. Conn Holohan and Tony Tracy (Basingstoke: Palgrave Macmillan, 2014). television series Mrs Brown's Boys (BBC 201114). Ireland as a country has traditionally been feminised, associated with the Virgin Mother and likened to 'Mother Ireland'. Gerardine Meaney writes how the "image of Ireland as sweet, wild girl" or alternatively "as suffering and nurturing mother" ${ }^{\text {"3 }}$ has been common in pop culture. In Irish cinema specifically, the relationship between mother and son has been represented again and again. Ruth Barton and Martin McLoone have identified the recurrence of Oedipal narratives in the films of Jim Sheridan and Neil Jordan, and also in Celtic Tiger cinema. ${ }^{4}$ As well as the doting mother, Irish film has tended to be distinguished by the absent or ineffectual father figure. According to Debbie Ging, "the dysfunctional father trope persists in contemporary Irish cinema". 5

Glassland expresses consciousness of this traditional mode of representation, seeking to both perpetuate the 'mammy' and turn the stereotype on its head. There are in fact three mothers in the film - John's mother, Jean; Shane's mother, Bridie (Darine Ní Dhonnchadha); and the mother to Shane's son, who appears briefly near the end of the film. Bridie is the most traditional 'mammy'.

Bridie works with Jean in a kitchen, which is a notably conservative and traditional space associated with the maternal figure. She takes care

3. Gerardine Meaney, Gender, Ireland and Cultural Change: Race, Sex and Nation (New York: Routledge, 2010), 7.

4. See Ruth Barton, Irish National Cinema (London: Routledge 2004); Martin McLoone, Irish Film: The Emergence of a Contemporary Cinema (London: British Film Institute 2000).

5. Debbie Ging, Men and Masculinities in Irish Cinema (Basingstoke: Palgrave Macmillan 2013), 102. 
of both Shane and John, feeding them and bringing them tea at Shane's beck and call. In one scene, Bridie joins the boys as they play a game on a Playstation. She warns Shane about his bad language when he curses, and also asks John how his mother is, thus signifying the teaching but also the caring role that is synonymous with the 'mammy'. She can be a little over-bearing, for example, insisting on taking a picture of John and Shane before Shane leaves to go abroad, and while Shane gives out about this, immediately afterwards (in one of the more humorous moments of the film) she gives Shane his passport, which he almost forgot, before he leaves. She thus proves her worth as the practical mother who remembers everything, and when the boys drive off, the camera lingers on her to capture the sadness of a mother whose child is leaving home.

Bridie works with Jean in a kitchen, which is a notably conservative and traditional space associated with the maternal figure. Jean, on the other hand, is associated with the destruction rather than the maintenance of the domestic space, destroying plates and attempting to tear the house apart at one point in the film when she is looking for alcohol. While she is aggressive and clearly causes John a great deal of anxiety, she also expresses a great deal of affection towards him. When she explains the circumstances that led to her alcoholism (She tells John about how her partner, his father, left when Kit was born, and then her family and friends refused to see her), the character becomes humanised and highly sympathetic. This sense of a three-dimensional character, who is loving but also full of rage, flawed but idolised by John, signifies Barrett's wish to break down the mammy stereotype and to show the variety of hardships that mothers may face.

The theme of alcoholism is another that sees revision here. Binge drinking is a major problem in Ireland, leading to high rates of depression and death. ${ }^{6}$ In a recent WHO report, the country was named the eleventh highest consumer of alcohol

6. "Alcohol and Health - Alcohol Action Ireland", http://alcoholireland.ie/facts/health-and-alcohol/. per capita in the world. ${ }^{7}$ The "drunken Irish" tend to appear humorously in film, used by auteur John Ford in the past but also in more recent features, for example, Grabbers (Jon Wright 2012) follows a community in a small Irish town who have to get drunk in order to ward off an attack from an alien invasion. In Glassland, alcohol is not glamorised. Rather, the physical, emotional and psychological damage of alcohol addiction is emphasised. When Jean is submitted to hospital after OD'ing, the doctor tells John that she will eventually need a liver transplant, but worries she will not even live to have that operation. "She's systematically killing herself every day slowly", he tells John. In the film's most powerful scene, John has driven Jean to a clinic but she refuses to go in. John explodes at her, saying: "I'm sick of cleaning up your vomit, I'm sick of dragging you in off the doorstep like a fucking animal...I'm sick of watching you walk around that corner to work every morning and not knowing whether you were gonna come home", eventually screaming "I'm sick of it, I'm fucking sick of it, sick of it, sick of it!" His repeated use of the word 'sick' emphasises that his mother's condition is actually an illness, which is reinforced when the counsellor they see, Jim (Michael Smiley), tells John that what Jean has is a "disease".

$\mathrm{Jim}$ is a nurturing, soft-spoken and considerate character who goes considerably out of his way to help John and Jean. Interestingly, Jim is the only adult man we see in the film. The visual absence of men here (for example, we hear the voice of the pimp who John contacts to borrow money from to pay for his mother's rehab but do not see him) seems to emphasise the visible lack of male role models or positive father figures in John and Shane's lives. John's father has left and while Shane's is still around - again, the audience never actually sees him in the course of the film - he refuses to come outside to wish his

7. "Revealed: Where Does Ireland Rate on the List of the World's Booziest Countries? - Independent.Ie", http://www.independent.ie/life/health-wellbeing/ health-features/revealed-where-does-ireland-rate-onthe-list-of-the-worlds-booziest-countries-34346823.html. 
son goodbye before he leaves to emigrate, thus suggesting there is an emotional distance between the two. In the absence of their own fathers, however, John and Shane represent alternative paternal figures who provide more positive role models than what they have been shown. This is evident from the fact that Shane wants to see his son (as opposed to Shane's father who won't see his son off), and through John's taking up of a number of domestic duties traditionally associated with parents. He cleans the house, does the shopping, feeds his mother, puts her to bed, and lectures her about the outcomes of her tantrums. In a particularly tender moment, he dances with Jean in the hospital, having been told by her at home that she misses dancing with his father. Gerard Barrett has said in an interview:

after college I moved to Ireland, and the first thing that struck me was kids parenting their parents. Mothers and fathers battling addiction and it was falling on the kids to pick up the pieces and parent them. A complete role reversal. I found it absolutely fascinating. ${ }^{8}$

While John and Shane are on the brink of adulthood and do take up parental roles, they also relish the opportunity to act like children again, for example, hanging out in the arcade and playing games at Shane's house. In their youth, homosocial friendship, participation in leisure activities, and 'slagging off' of one another, the young men also exemplify the 'lad', a figure that has appeared in Irish film since the turn of the millennium and has been written about extensively in the work of Debbie Ging. ${ }^{9}$ Here, however, the Irish lad has been rewritten into a more expressive and caring figure than before. While Shane can evidently be aggressive, for example, in his confrontation with the rental store employees, he is also a responsible father, providing child support and determined to see his

8. "Glassland: Behind the Scenes with Director Gerard Barrett", http://www.movies.ie/glasslandbehind-the-scenes-with-director-gerard-barrett/.

9. See Ging, Men and Masculinities in Irish Cinema. son. When he is finally reunited with him, they play games together and express great joy in each other's company, sharing an affectionate hug as they say goodbye. Shane and John talk about the challenges they face in their respective lives with one another, and in the scene where John gives out to his mother outside the clinic, he touchingly expresses a dependency for his mother - "I want my mother back, I need you. You're breaking my heart every single day".

As the lead, John is the most important figure in demonstrating this reconstitution of the young lad into a 'new man' ${ }^{10}$ who expresses his emotions and is devoted to his friends and family. The casting of Jack Reynor in the role is of great significance in this regard, having previously played 'D4' 'laddish' types in films such as Dollhouse (Kirsten Sheridan, 2012) and What Richard Did (Lenny Abrahamson, 2012), the latter being his breakthrough role. As the titular character, Reynor brought a sense of menace and maturity to that role that was beyond his years, and the actor received similar acclaim for his role in Glassland. Total Film wrote "this is Reynor's film and he holds the screen like a pro - always thinking, tapping, twitching with silent fury" ${ }^{11}$ This 'silent fury' can be seen in the moments where John searches for his AWOL mother, or at work giving taxi rides, and it explodes when he finally confronts his mother about her problem. However, he never expresses dissatisfaction with the way his life has turned out, but simply accepts that he is the one who has to mend his broken family and to put others before himself. At the same time, the fact that when he is alone he often looks through windows, evokes the sense that he feels trapped by life, desires more, and is eager to get out and see new things. The character of John sees new potentials for the Irish father and also revises the image of the Irish son or 'lad' in film. In Jean, John and Shane, we are presented not with stereotypes but deeply complex, conflicted,

\section{See John Beynon, Masculinities and Culture} (Buckingham: Open University, 2001).

11. Matt Glasby, “Glassland Review”, http://www. gamesradar.com/glassland-review/. 
three-dimensional characters which arise from the struggles of contemporary life in Ireland.

The only major shortcoming of Glassland is its ending. In order to borrow money to pay for his mother's rehab, John is required to carry out some shady work which is ambivalent and confusing to the audience. The repercussions of his final act are also unclear. Nonetheless, Glassland stands out as a well-written and exceptionally well-acted Irish film. Its revision of the Irish family unit could have far extending influences than are apparent at this moment in time.

Deirdre Molumby is an MLitt in Film Studies candidate at Trinity College Dublin, Ireland. 


\title{
The Great Wall (Tadhg O'Sullivan 2015)
}

\author{
Michaela Marková
}

According to the UN Refugee Agency, the year 2015 marked the record number of migrants and refugees across the world, particularly in the EU. Since April, when five boats carrying almost two thousand emigrants to Europe sank in the Mediterranean Sea, the phrases "European migrant crisis" and "European refugee crisis" have become the commonly used in the media. Issues concerning ways of coping with this influx now incessantly preoccupy the EU Parliament. Measures proposed to be taken have varied. The precaution introduced in Hungary, euphemistically called the "Great Wall', has given rise to much bitter controversy. This protective measure, however, Tadhg O'Sullivan's eponymous feature documentary informs us, is neither an isolated nor the least problematic one implemented by the EU. However, instead of criticising specific governments and particular barriers, The Great Wall explores political geography, articulation of power and the motives of those responsible for making decisions about borders of inclusion and exclusion.

O'Sullivan's The Great Wall is a conceptual and at times rather abstract artistic treatment of the abovementioned issues. It strongly resembles essayistic film work by the late French director and multimedia artist Chris Marker. Therefore, it might be more apposite to call The Great Wall an essayistic film rather than a documentary, particularly as the work does not follow linear narrative style. Indeed, organizing his contemplation thematically as well as structurally is O'Sullivan's appropriation of Franz Kafka's short story "The Great Wall of China". ${ }^{1}$ Despite

1. "The Great Wall of China" is a short story written by Franz Kafka in 1917. It was not published until 1931, seven years after his death when Max Brod selected stories and published them in the collection Beim Bau der Chinesischen Mauer. the different media and the different periods, Kafka's poetic exploration of leadership's competence to make decisions, including those about national protection, complements O'Sullivan's project well. This is due to timelessness of the major topics the works examine. Both works scrutinize the ideological construction of otherness. Both also bring out fundamental patterns of human behaviour one adopts in relation to "the other". O'Sullivan seeks for the audience to engage in a dialogue on those topics, which is apparent from the specific work of camera throughout the film. The images presented are thematically related yet random and their sequencing might seem incoherent to some. The Great Wall, nevertheless, does not turn into a tangential mess due to careful direction and editing. The overall outcome becomes a social critique with taut, kinetic progression towards a synthesising message, the urgency of which is enhanced by the accompanying soundtrack and O'Sullivan's masterful sound design for which he is well known.

In its lyrical, visual elaboration of "the other" question, The Great Wall draws the viewer's attention to the liminal states that tend to be the EU buffer zones aimed at preventing the influx of illegal immigrants. It manifests how one's desire for stability affects the way people treat the unknown, and hence potentially threatening, "other" - they build barriers, visible as well as invisible. Barriers that grow with the increasing level of fear "the other" instil. The fact that this fear of "the other" might be informed by the aforementioned desire for stability rather than substantiated is alluded to by Kafka's aphorism which opens the film: "A cage went in search of a bird". The cage, a parable for the walls, is a man-made object. The implied focus is on those who argue that to fear "the other" is justifiable even though there might not be any proof for such 
a claim and demand for the walls to be built. This behaviour fuels fear society. Consequently, The Great Wall inspires the viewer to question ambivalence that is central to stereotypes. It was such ambivalence, a scene depicting the old fortress in the Spanish city of Melilla in mainland Africa suggests, which gave colonial discourse its currency. This ambivalence also ensured that deterrent structures have a long and challenging tradition in European history. Indeed, it contributed to repeatability of stereotypes in changing historical conditions as the new Melilla border barrier constructed to stop illegal immigration to the EU is not that far from the old colonial fortifications. The ambivalence typical of stereotypes is in contrast to the ambiguity of O'Sullivan's work itself. The documentary avoids showing any recognizable landmarks, yet the scenes it depicts seem only too familiar to the audience. This artistic choice and O'Sullivan's image framing help to create the feeling of a universal mise-en-scène which further underlines universality of the discussed issues.

In its questioning of ambivalence as the strategy of discriminatory power, The Great Wall mirrors Bhabhian analysis as it challenges the positions on the meaning of exclusion and oppression. However, The Great Wall challenges the motives behind the construction of alleged protective walls even further. Through its use of visual imagery combined with the excerpts from Kafka's story, the documentary averts to the negative impact of globalism. Shots of fleeing refugees and migrants trying to cross barriers are contrasted with those of businessmen in expensive suits on the streets of the bastions of EU commerce and control, such as London. This issue is, similarly to the other ones the documentary discusses, linked to colonial misuse of power and resultant supremacy via shots of the fortress in Melilla and the exposition of colonial acquisitions it houses. While the documentary also hints at the role ordinary people play in capitalism, O'Sullivan's examination of the electorate's responsibility concerning the actions the EU leadership takes in its name seems more poignant. The Great Wall invites the audience to ponder its own agency. It raises the question whether people should think for themselves, challenge their leadership's conduct and if so to what extent. In other words, the film asks whether people, to use a parable from Kafka's story, should become rivers which burst their banks.

O'Sullivan's The Great Wall constitutes an invaluable contribution to the discussion of current affairs. It is thus fortunate that the filmmaker received support from the Arts Council's Reel Art scheme. Yet, it is necessary to say that even though O'Sullivan is passionate about the subject; his film prefers to convey its message in a visually and poetically artful manner rather than as polemic. Although the voice over of excerpts from Kafka's work (narrated in the original language of the story with accompanying English subtitles) and the captivating soundtrack might condition the way the audience perceives the visual imagery, this conduct is not as intrusive as direct address applied in documentaries can often be. The Great Wall is no propagandistic manifesto but the audience might nevertheless feel compelled to ponder its themes and to take a stand. The decision to do so, however, is their own, as are the consequences.

Dr Michaela Marková took a $\mathrm{PhD}$ at School of English, Trinity College, Dublin. Her dissertation discussed narrative strategies in contemporary Northern Irish Troubles fiction. Her research interests are contemporary literature in English, urban anthropology and psychogeography. She is the co-editor of Politics of Irish Writing: A Collection of Essays (2010), Boundary Crossings (2012) and Tradition and Modernity (2014). 


\section{Rebellion (Colin Teevan / RTE 2016)}

\section{Sheamus Sweeney}

2016 marks the centenary of the 1916 Easter Rising, a pivotal moment in Ireland's revolutionary period, and the event from which the modern Irish state traces its inception. Rebellion is RTE's dramatic centrepiece to mark the halfway point in what has been described as a decade of commemorations. Reaction to the five part series has been "mixed" to put it mildly. Criticism has ranged from its perceived historical inaccuracies and politically motivated revisionism, to more general flaws of execution, with a melodramatic storyline that seems to owe more to ITV's Downton Abbey than a historical epic. John Boland (2016) felt that it failed to convince, "largely because [the writer] Teevan had come up with embodiments rather than individuals, character types that could be ticked off a checklist." Bernice Harrison (2016) excoriated its attempts to exert its feminist credentials by placing women at the centre of the narrative, while replacing the female nurse who carried the white flag at the rebels' surrender with a man. The public also seemed to tire as the weeks passed, with first run audiences dropping from 619,000 in the first week, to 487,000 by week four (Slattery 2016). One dissenting voice was Eoghan Harris (2016) in the Sunday Independent, who praised the drama's apparent courage in proving that the Irish, and not "the Brits", were the architects of their problems.

It is Harris's evaluation of the series' alleged strengths that points toward its greatest weakness. For a drama intended to tell the story of a rebellion against what was then the most powerful empire on earth, there is little sense of any context beyond the parochial and insular concerns of the (mostly) Dubliners involved. There is little sense, as Justine McCarthy (2016) points out, that "anti-imperialism was a growing movement around the world in the late $19^{\text {th }}$ and early $20^{\text {th }}$ century". However, while Rebellion can be denounced or praised for many of its constituent elements, whether perceived revisionism, anachronistic dialogue, or Downton Abbey pretensions, the main problem lies in its refusal to properly commit to any of them in a way that makes for convincing and compelling drama.

Written by Colin Teevan, whose previous credits include the 2015 drama Charlie (on former Taoiseach (Prime Minister) Charles Haughey), the series had a - by RTE standards substantial reported budget of $€ 6 \mathrm{~m}$ (Brosnan 2016). This is small in global terms, but the production still looks relatively impressive, not least because it was able to shoot on location at many of the key buildings from the period. Arguably the most surprising aspect is the decision taken by the national broadcaster not to commission an Irish-based company to lead the production, opting instead for the Parisheadquartered Zodiak Media (albeit Element Pictures played a co-producer role). As a consequence, although most of the key creative personnel were Irish, two senior crew members director (Aku Louhimies) and editor (Benjamin Mercer) - are Finns. That the national broadcaster subcontracted out the making of a drama about one of the foundational moments of the state to a multinational melange of production companies says a lot about the economic orthodoxy in Ireland in 2016.

Therefore Rebellion was apparently commissioned with two intentions. The producers seem to have been intent on creating something with enough period drama flourish to appeal to audiences enthralled by Downton Abbey or Poldark (BBC 2015). (This paid off even before the series was completed with Sundance TV in the US acquiring US rights to

ISSN 1699-311X 
the show at MIPCOM in October 2015). In interview Teevan has spoken of his desire to create a drama that deliberately sidelined the rising's major figures in favour of a more bottom up perspective, especially the stories of habitually marginalised female characters, a decision which promised an innovative perspective on events. Teevan has noted how unaware he was of the prominent role of women during the Rising, declaring himself "'astonished' by the numbers involved once he had researched the period" (McGreevy 2016). He cites Dr Kathleen Lynn as an inspiration for some of the characters, before curiously claiming that "the Irish Citizen Army was a strange alliance of middle-class women and workingclass men. That really led me to the stories of the women" (ibid.). This revelation would come as news to working class women of the Irish Citizen Armylike Rosie Hackett (whose name adorns a new bridge over the river Liffey). While there is an element of truth in Teevan's statement, it elides the far greater prominence of working class women, like Hackett and Helena Molony. It also ignores the more radical truth that the Citizen Army was the only organisation that went into action in 1916 with working class men and women fighting together. Furthermore, the equation of working class men with middle class women is an interesting illustration of their relative places in the hierarchy of marginalised voices. Working class women of course are largely voiceless. The most prominent "working class" woman in the drama is not one of the three main characters, but a prostitute-cum-pettythiefcum-looter, albeit her criminality is contextualised by her poverty.

With the parts of medical student Elizabeth Butler played by Charlie Murphy, Cumann na mBan member Frances O'Flaherty by Ruth Bradley, and Brian Gleeson playing Citizen Army soldier Jimmy Mahon, there are obvious intertextual associations with RTE's Love/Hate. In one sense that crime drama is the nearest analogue to Rebellion in terms of approach to its subject. Both tell stories that cry out for contextualisation, while settling for a frustrating preoccupation with minute and individual moti- vations that fail to resonate with wider themes. In both cases the depiction of working class life seems largely composed of violence and criminality.

The lack of context means that there is also little sense of why the rebellion actually happened. As Tom Stokes observes in a recent review:

There has been no attempt so far to explain the motivations behind the revolution apart from the need to break the link with the coloniser. Without those motivations being referred to the revolution is just an amateurish enterprise inspired by nationalistic grievance (Stokes 2016a).

Some curious dramatic choices are made, particularly in the need to create some kind of immediate cause for the Rising itself. The "Castle document" is included, an apparent plan by the British administration to arrest prominent nationalists, but which is still subject to debate as to whether or not it was genuine (Townsend 2005: 131-3). Regardless of its actual provenance, in the drama it is smuggled out of the castle, not in an act of nationalist rebellion, but in a fit of pique by the jilted May Lacey (Sarah Green). Similarly, a second episode scene depicts the cold-blooded shooting of a woman by a member of the Irish volunteers. Although although the Volunteers may in fact have shot at those looting shops near Rising hotspots, in this case this woman is not depicted as a looter leaving her murder unexplained. Even more curious, is the inclusion without context or explanation of a summary execution by the British Army. Tom Stokes (2016b) asks the question, "Why might it be important to know that he [the executed man] was Francis SheehySkeffington, a journalist, an advanced-feminist, a pacifist who had played no part in the revolution itself?" That only those with previous knowledge of the period will make this connection further raises questions about the utility of the drama in terms of recounting the story of 1916.

Similarly, while it is one thing to tell the story of the Rising from a number of perspectives, it is another to treat its organisers as both incidental and one dimensional. Michael Collins, a minor figure at this time, is accorded nearly as much 
screen time and dialogue as James Connolly. Indeed, Connolly, who has left a collection of readily available writing from which to fashion some dialogue, is largely silent throughout. When, in an entirely speculative fourth episode encounter with British civil servant George Hammond, he does expound at some length, he speaks in nationalist clichés, his socialist beliefs left unreferenced.

With its nods to period costume drama, Rebellion recalls earlier co-productions of Irish historical drama. In 1982 The Year of the French retold the United Irishman rebellion of 1798, and was produced, appropriately, with French channel FR3 and Channel 4 in Britain. Commercial logic suggested that the subject matter should prove appealing to a French and an Irish audience. This proved not to be the case, with the finished product containing lots of decontextualized battle scenes, superficial political engagement and interpersonal intrigue (Sheehan 1987). Similarly in Rebellion, heavily telegraphed allegorical domestic troubles are included at the expense of any attempt to contextualise what was happening. The story of 1916 is swamped "in a drama largely about the comings and goings of establishment families and characters" (Stokes 2016c).

Responses to the drama on social media focussed on perceived historical inaccuracies, from the inclusion of the "Castle document", to the caricatured representation of Constance Markiewicz, who appears only once and comes across as both unhinged and in possession of an unfeasible Dublin accent. Eamon deValera is represented as cowardly, incompetent and devious. By contrast, the appearances of Michael Collins underline his confident presence, and bluff amiability, counterposing the pragmatism of the most famous treaty signatory against a collection of semi-delusional romantics. The contrast is underlined particularly forcefully in episode three, which sees a speech by Padraig Pearse intercut against Jimmy Mahon and Elizabeth Butler grieving the death of the former's nephew. Pearse is raving, amid the götterdämmerung of the GPO, about how their children will reap the fruits of their sacrifice.
While the Irish Citizen Army is represented more sympathetically, at least in terms of motivation, aspects of their depiction also raise questions. In the second episode Jimmy, sitting in Liberty Hall, quotes from a pamphlet by Lenin. That English translations of Lenin pamphlets were available in Dublin in 1916 seems implausible at best. Regardless, Jimmy is sitting in Liberty Hall, where Ireland's first socialist newspaper is written and printed and where the works of the socialist James Connolly (not to mention the author himself) would have been far more accessible. The effect, through ignorance or design, underlines the idea of socialist thought and class conflict as a foreign import, and not something that emerged naturally from the social conditions in Dublin at the time.

These social conditions are paid lip service, but seem barely visible, in a city with the worst slums in Europe, barely three years after a protracted labour lockout. The depiction of urban squalor seems lifted from a stage production of Les Miserables. There is also little sense of the slums, or of people living on top of each other. The Mahon's room compares favourably with some flats available for rent in Dublin in 2016, resembling nothing so much as an unimaginative staging of O'Casey. In this regard, the series compares badly with Strumpet City (RTE 1980), which successfully evoked the sense of claustrophobic damp and darkness of people living in close proximity, and where access to space was a clear marker of class privilege.

The most noteworthy aspect remains the inclusion of three prominent female characters, in a television landscape where a single female lead remains unusual. Unfortunately, as the earlier cited comment by Bernice Harrison suggests, they are ill-served by the script. Niamh Horan (2016) suggests that this female representation partly consists of a prostitute "asking soldiers if they 'fancy a f*ck?' and a scene where the two main female leads tear shreds from each other over the men in their life", while "afterwards, social media was alight with praise simply because the storyline 'revolved around women"'. In fact, all three women are defined by the men in their lives. Elizabeth's 
decision to throw in her lot with the Rising on her wedding days seems at least partly motivated by her attraction to Jimmy. She runs from one man to another. Frances Flaherty is platonically en thrall to Pearse, and having spent most of the series dressed as a man, Frances reveals that she has romantic feelings for May at the very end. The inclusion is tokenistic and ill-judged, particularly as it seems to conflate Frances's sexuality and gender identity with her emerging ruthlessness. The final scene shows Frances shooting a police detective in the back of the head, on a Dublin street.

It also points up a central problematic with the drama's approach to marginalised voices. There were a number of gay women active during the Rising one of whom, Kathleen Lynn, appears in Rebellion as Elizabeth's superior in the Citizen Army. Lynn was a doctor, who fought alongside her partner Madeleine ffrench-Mullen during Easter week, living with her for decades afterwards (Sheehan 2016). Elizabeth O'Farrell, who carried the white flag at the surrender, and who is replaced by a man in Rebellion is buried in the same grave as her partner in Glasnevin cemetery (ibid). If the intention was to tell the story from the point of view of those whose narratives have been suppressed, there is no shortage of those on whom to base narratives of radical politics and life experience, to help contextualise the roots of the rebellion.

As Robert Rosenstone has argued in his numerous engagements with the genre of the historical film, "it is precisely at the level of argument and metaphor, particularly as these engage the larger discourse of history", that its contribution lies (2006: 39). Insofar as the drama expresses a coherent political perspective on the events, it is that the Rising was a reckless, ill-thought out, and naïve piece of adventurism, launched with a callous disregard for the inhabitants of Dublin, and made immeasurably worse by the stupidity of the
British response. Furthermore, while there were undoubtedly many Irish men in the British Army at the time, the extent to which they are foregrounded in Dublin during the early days of the Rising seems to reconfigure the conflict more as a civil war, could perhaps best be characterised as one that manages to blame both the Irish and British simultaneously. While this might seem to place it in a rather ecumenical position with regard to debates around 1916, it also suggests a dramatic point of view strangely detached from history. However, the subtext of the conclusion potentially makes a different argument. This seems to suggest that the rebellion and its aftermath were irruptions into a relatively stable social order, where progress was being made, especially in the shape of its feminist protagonists. It closes with Elizabeth's drunken wastrel brother, who has inherited the family fortune, declaiming his "plans for this new hibernian world" in the company of his working class prostitute companion. What are we to make of this? Are these the people who will inherit the country?

It has been suggested that this is merely the first part of a trilogy of dramas to chart the revolutionary period in Ireland, with further instalments about the War of Independence and Civil War (Blake Knox 2015). In this respect, the ending of Rebellion may come to make some kind of retrospective sense. However, these are periods which have already received significant attention from more politically motivated filmmakers, albeit of differing ideological leanings; Neil Jordan's pro-Treaty Michael Collins (1996) biopic, and Ken Loach's socialist revisionism of the same period, The Wind That Shakes the Barley (2006). To build on the achievements of each, RTE will need to produce something more substantial than a drama that pursues international sales by gutting the period of its radical underpinnings.

\section{Works Cited}

Blake Knox, Kirsty. 2016. "Women central to drama that makes history feel new". Irish Independent, January 5 .2-3. .2015. "RTE plans second series of 'Rebellion"”. Irish Independent, December 22. 20. 
Boland, John. 2016. “RTE’s 1916 history lesson lacks a touch of real drama”. Irish Independent, January 9. 18.

Brosnan, Sean. 2016. "Rebellion's Ruth Bradley talks improv and empowering female characters” IFTN.IE. Accessed 22 February 2016.

http://iftn.ie/?act 1=record\&aid=73\&rid=4288885\&sr=1\&only=1\&hl=Rebellion\&tpl=archnews.

Harris, Eoghan. 2016. "Blame the Irish dogs that did not bark in the night-time". Sunday Independent [online], January $31^{\text {st }}$. Available from: http:/www.independent.ie/opinion/columnists/eoghan-harris/blame-the-irishdogs-that-did-not-bark-in-the-nighttime-34410186.html [Accessed 14 February 2016]

Harrison, Bernice. 2016. "Truth of rebellion more dramatic than this fiction". The Irish Times, February 1. 4.

Horan, Niamh. 2016. "Brave rebels turned into doe-eyed girls. Sunday Independent, January 10. 14.

McGreevy, Ronan. 2016. “TV writer amazed at women's 1916 role”. The Irish Times, January 11. 3.

Sheehan, Maeve. 2016a. "Lesbians of 1916 are the Rising's 'hidden history”". Sunday Independent, January 24. 28. .2016b. They gave everything for their country and were then overlooked. Sunday Independent, January 10. 14.

Scally, Aisling. 2015. "The (euro) 6m haul”. Irish Daily Mail, December 22. 3.

Slattery, Laura. 2016. “'Rebellion' surrenders its hold on viewers”. The Irish Times, January 26. 4.

Stokes, Tom. 2016a. "The deliberate disaster that is RTE's 'Rebellion'”. The Irish Republic, January 11. Available from: https://theirishrepublic.wordpress.com/2016/01/11/the-deliberate-disaster-that-is-rtes-rebellion/ [Accessed 14 February 2016]

. 2016b. 'RTE's 'Rebellion' series, and its propaganda value”. The Irish Republic. January 18. Available from: https://theirishrepublic.wordpress.com/2016/01/18/rtes-rebellion-series-and-its-propaganda-value/ [Accessed 14 February 2016]

. 2016c. 'RTE's 'Rebellion' - slandering heroes while creating dross". The Irish Republic, January 25. Available from: https://theirishrepublic.wordpress.com/2016/01/25/rtes-rebellion-slandering-heroes-whilecreating-dross/ [Accessed 14 February 2016]

Tipton, Gemma. 2016. “Great Irish homes with added drama”. The Irish Times, January 28. 13.

Dr. Sheamus Sweeney lectures on media and communications to Boston University's Dublin Programs hosted by Dublin City University. In 2013 he was awarded his doctorate for a study of David Simon's HBO series The Wire. 


\section{Used to Live Here (Frank Berry 2015)}

Tony Tracy

Frank Berry is an emerging Irish-film maker who received widespread praise for his preceding, debut film, the feature-length documentary Ballymun Lullaby (2011) (reviewed in Estudios Irlandeses 7). ${ }^{1}$ Building on several years of community film-making experience, that film followed a local community music project commissioned to mark the regeneration of Ireland's least loved social experiment: the Ballymun tower blocks scheme. The film's formal conventionality (primarily a series of interviews interspersed with footage of rehearsals) belied the energy of its message of hope and renewal, incarnated by dynamic music teacher Ron Cooney, who inspires his young singers to rise above the everyday circumstances of their lives through song. Berry's film did a major service in overhauling Ballymun's persistent on-screen depiction as a social failure evident in films such as Pigs (1984), Into the West (1992) and Adam and Paul (2004). Its infectious energy and life-affirming portrait of community stirred audiences who had never heard of the deprived neighborhood as well as those whose minds were long made-up. After a limited cinema release in Ireland (an achievement in itself for a 'no-budget' documentary feature), it won the Directors Finders Series 2011 (a joint initiative between Screen Directors Guild of Ireland and Directors Guild of America) and represented Ireland as the closing film of the 'European Film Weeks 2011' in Helsinki, Finland.

The success of Lullaby afforded Berry the opportunity to embark on a long-held ambition to direct a fiction feature film. I Used to Live Here

1. Denis Murphy, 'Ballymun Lullaby', Estudios Irlandeses 10. 213-5. http://www.estudiosirlandeses. org/ reviews/ballymun-lullab. is the result and it marks an assured debut that builds on the writer/director/producer's commitment to give expression to contemporary Dublin working-class youth while exhibiting a distinctive cinematic voice. The starting point of the film for Berry was a number of Irish Times articles dealing with young suicides by psychologist Dr. Tony Bates, an authority on depression and Director of Headstrong - The National Centre for Youth Mental Health. ${ }^{2}$ After exploring his proposal to develop a feature film on the subject with Bates, Frank Berry visited the suburb of Killinarden, Tallaght, first as an observer of Headstrong workshops, then as facilitator. Arising from these sessions a number of story elements emerged which Berry then honed into an 80 minute script which is performed by a cast of local, non-professional actors.

The film centres on Amy Keane (Jordanne Jones), a 13-year-old trying to cope with the death of her mother, and the events in her life over the course of an eventful and emotionally demanding week. In an early scene she meets an acquaintance - Joe - in the supermarket during which she awkwardly sympathizes with him on the death of his brother. How the brother died is not made clear and the paradoxical status of suicide within sections of Irish society simultaneously taboo and rampant - is made clear the following day when she discovers that Joe has also died. As she and her peers walk past the spot where the boy jumped to his death the camera cuts to their writing 'R.I.P Joe' in and around the scene in marker; crude but touching gestures of condolence and memorial. We do not

2. Dr. Tony Bates speaks about youth suicide on a DVD extra for the film: https://www.youtube.com/ watch? $\mathrm{v}=\mathrm{wUEBCZRDhss}$. 
witness the funeral and while this absence jars somewhat from a narrative standpoint (there are several similar ellipses in the film), it powerfully evokes both the silence around this social epidemic as well as the loss of Catholicism as a structuring system of meaning in Irish society, an absence in the film that extends to other institutions such as education, law and social services. While there are memorable -through fleeting - glimpses of community (particularly an old friend of Amy's mother who offers to do her nails) the overall picture that emerges is one of isolation. While the setting is familiar from the stories and films of Roddy Doyle, an altogether bleaker picture of working-class suburbia emerges here with youths hanging around with little to motivate or engage them and vulnerable to the pressure of others or, more just as often, themselves.

While a difficult topic, the film is carried by Jordanne Jones' compelling presence and performance as Amy which modulates a wide emotional range from vulnerable child to stroppy youth and mature young woman; her calm exterior masking a turbulent inner life. While coming to terms with her mother's death, Amy is also coping with her emerging sexuality and, accordingly, an uncertain and shifting dynamic with her father Raymond (James Kelly) to whom she is alternately a daughter and adult partner. To further complicate matters, Raymond - a man caught between decency and desperation - is going through his own crisis as former girlfriend Dina (Alicja Ayres) returns and asks for a paternity test relating to her infant son. With little alternative, he allows Dina and the baby to move into his family home 'for a few days' provoking frustration, sarcasm and anger in his emotionally vulnerable teenage daughter. Beyond her home Amy isn't doing much better in terms of emotional stability. Her closet friend Dylan (Dafhyd Flynn) is an introverted boy who's being hounded by local drug dealing bullies. His reticence drives her towards a budding romance with another teen which begins promisingly but quickly turns to disappointment and humiliation.
The world which Amy and Dylan inhabit is thus one where self-confidence and personal dignity is under constant threat and where suicide is a known, if taboo, mechanism of 'escape'. Beyond breaking that silence, the film's message - if it can be said to have one - is that while emotional confusion and pain is a common, even defining experience of young people's lives, suicide does not remove that pain, but extends it to the loved ones and wider community left behind. Thus, one of the film's most touching moments is when Raymond realizes that his daughter is in danger and rushes to comfort her. This moment of awareness, in which the father reclaims his role, has the potential to save both of them. Others, through lack of vigilance or inarticulacy, may not be so fortunate.

I Used to Live Here ennobles its often grim settings and themes through naturalistic performances of integrity and a simple but credible screenplay grounded in experience. In both style and content it eschews the AngloAmerican ambitions of much contemporary Irish cinema (although it should be remarked that its world is less bleak than another contemporary family drama Glassland, also reviewed in this issue) and while it clearly differs in ambitions and production values, it deserves to be as included with films such as Brooklyn and Room (each of which, notably, also foreground female protagonists) in celebrations of the vibrancy of indigenous film production. Shot on a low-fi digital format that reinforces a sense of social marginality, the film's minimalist style, cinematography and concern for young and vulnerable characters connects it to the cinema of Robert Bresson and the Dardenne brothers, even if it eschews the transcendent themes often present in those film-makers' work. Frank Berry has also cited the influence of the Romanian New Wave - which is evident in the film's muted color palate and dour realism - but this is a film underscored by hope, more committed to the redemption of the individual than social determinism. A key stylistic element in this regard is Daragh O'Toole's brilliant score which creates a spare but evocative sonic evocation of 
the film's psychological theme. ${ }^{3}$ In this delicately poised emphasis on hope, I Used to Live Here is more Christian than Socialist in impulse; closer to Bazin than Eisenstein or what

3. The soundtrack won an IFTA in 2015. Some examples can be found here: http://daraghotoole.ie/work/. might be termed post-Thatcher British realism. Amy is deeply vulnerable but never entirely lost and Jordanne Jones' subtle performance is a significant contribution to the canon of Irish cinema both on its own terms and also in relation to representations of class and gender.

Dr. Tony Tracy lectures in film theory and history at Huston School of Film and Digital Media, NUI Galway where he directs the BA programme. His research specialisms are Irish Cinema and silent and classical era Hollywood. His most recent publication is "Outside the System: Gene Gauntier and the Consolidation of Early American Cinema", Film History: An International Journal 28.1, 2016. 